JULIANA VELASCO DE CASTRO OLIVEIRA

\title{
EXPRESSÃO TEMPORAL DOS GENES DO NUCLEOPOLIEDROVÍRUS Anticarsia gemmatalis E SUA INFLUÊNCIA SOBRE A CÉLULA
}

Tese apresentada ao Programa de Pós-Graduação Interunidades em Biotecnologia USP/Instituto Butantan/IPT, para obtenção do Título de Doutor em Biotecnologia.

Área de concentração: Biotecnologia

Orientador: Paolo Marinho de Andrade Zanotto

São Paulo

2010 


\section{RESUMO}

Oliveira JVC. Expressão temporal de genes do nucleopoliedrovirus Anticarsia gemmatalis e sua influência sobre a célula. [tese (Doutorado em Biotecnologia)]. São Paulo: Instituto de Ciências Biomédicas da Universidade de São Paulo; 2010.

Desde a década de 80, o nucleopoliedrovírus Anticarsia gemmatalis (AgMNPV) tem sido utilizado no Brasil como agente de controle biológico no combate à lagarta-da-soja, resultando para o país significativos benefícios econômicos e ecológicos. Este vírus envelopado, pertencente à família Baculoviridae, possui DNA circular de fita dupla (132.239 pb) contido em um capsídeo protéico, que pode estar ocluído em uma matriz para-cristalina. Neste trabalho, analisamos a expressão temporal de seus genes em duas linhagens celulares (UFL-AG-286 e IPLB-SF-9), por PCR em tempo real. Outro objetivo foi o estudo do efeito da multiplicação viral na malha gênica celular (GRN), visando analisar a expressão gênica celular diferenciada durante a infecção, através da técnica de hibridização subtrativa. Verificamos que todas as ORFs (exceto ORFs 64 e 83, que provavelmente não codificam a genes) foram expressas, com diferenças significativas entre as linhagens, principalmente em relação ao nível de expressão. Apesar disso, o grupo de genes ligados a replicação apresentou perfil de expressão similar nas duas linhagens, possivelmente por este ser um processo essencial à replicação viral. De uma forma geral, todos os genes apresentaram um perfil de expressão mais precoce do que o relatado na literatura, o que poderia ser tanto devido à replicação precoce do DNA do AgMNPV quanto até mesmo consequência da sensitividade do método utilizado. O agrupamento dos genes por $k$-means seguiu, em sua maioria, a hora pós-infecção (p.i.) onde a expressão de cada gene foi detectada, o que é coerente com a expressão gênica em cascata de baculovírus. Entretanto, por esta classificação não foi possível predizer função gênica para os genes pouco caracterizados. Em relação ao efeito da infecção do AgMNPV na GRN da UFL-AG-286, observamos que em 20h p.i., uma grande diversidade de genes e funções celulares foram hipo-expressas.

Palavras-chave: AgMNPV. Baculovírus. Controle Biológico. Expressão gênica. Hibridização Subtrativa. 


\begin{abstract}
Oliveira JVC. Temporal expression of the Anticarsia gemmatalis nucleopolyhedrovirus genes and its influence on the cell. [Ph.D. Thesis (Biotechnology)]. São Paulo: Instituto de Ciências Biomédicas da Universidade de São Paulo; 2010.

Since the 80s, the Anticarsia gemmatalis nucleopolyhedroviruses (AgMNPV) has been used in Brazil as a biological control agent against the Anticarsia gemmatalis caterpillar in soybean fields, resulting in considerable economic and ecological benefits. This enveloped virus belongs to the Baculoviridae family. It has circular double-stranded DNA (132239 bp) enclosed in a capsid, which can be occluded in a crystalline matrix. In this work we elucidated the temporal gene expression profile of the AgMNPV-2D in two cell lines (UFL-AG-286 and IPLB-SF-9), using a real time PCR. Another objective was to study the effect of viral replication on the cellular gene regulatory network (GRN), in order to analyze the differential cellular gene expression during infection, using subtractive hybridization method. We found that most ORFs (except 64 and 83 ORFs that probably do not encode genes) were expressed, with significant differences between cell lines, mainly in expression intensity. However, the group of genes associated with viral DNA replication had similar expression profile in both lineages, possibly because replication is an essential process for viral multiplication. In general, most genes had earlier expression than reported in the literature, probably due to the early DNA replication in AgMNPV. Moreover, this could be a consequence of the method sensitivity used herein. We clustered genes with the $k$-means algorithm according to the time pos infection (p.i.) in which each gene expression was first detected and found it to be consistent with the typical cascade of gene expression known for baculovirus. Nonetheless, following this classification, it was not possible to predict gene function for poorly characterized genes. When looking at the impact of viral replication on the host GRN using subtractive hybridization, we found considerable inhibition of cellular transcription at $20 \mathrm{~h}$ p.i. Furthermore at this time, a large and diverse set of cellular genes and functions were found to be hypo-regulated, indicative of an extensive effect of AgMNPV infection on the UFL-AG-286 GRN.
\end{abstract}

Key words: Baculovirus. Biological Control. Gene Expression. Subtractive Hybridization. 


\section{INTRODUÇÃO}

\subsection{A Família Baculoviridae}

A família Baculoviridae compreende vírus que infectam mais de 700 espécies de artrópodes (O’Reilly et al., 1992), dentre elas organismos das ordens, Lepidoptera, Himenoptera, Diptera, Coleoptera, Orthoptera, Neuroptera, Siphonaptera, Trichoptera, bem como os das classes Crustacea e Arachnida. Embora a diversidade de ordens susceptíveis à infecção por baculovírus seja grande, cerca de $90 \%$ dos vírus conhecidos foram isolados de membros da ordem Lepidoptera (Martignoni e Iwai, 1981 apud Wang et al., 2008). ${ }^{1}$

Os baculovírus são vírus envelopados em forma de bastonetes (do latim baculum), constituídos por DNA circular de fita dupla com tamanho variando entre 80 e $180 \mathrm{~Kb}$ (Herniou et al., 2003), envolto por um capsídeo protéico (nucleocapsídeo), que caracteriza a partícula infectiva denominada vírion. Estes vírus podem ou não estar oclusos dentro de uma matriz paracristalina (os chamados corpos de oclusão) que morfologicamente divide os vírus em dois grupos: nucleopoliedrovírus (NPV) e granulovírus (GV). O corpo de oclusão dos NPVs é denominado poliedro, possui diâmetro variando de 0,15 a $15 \mu \mathrm{m}$ (Bilimoria, 1991) e é constituído principalmente pela poliedrina, uma proteína de aproximadamente $30 \mathrm{kDa}$ (Summers et al., 1980). Cada poliedro pode possuir um ou vários vírions por corpo de oclusão; além disso, os NPVs podem apresentar apenas um nucleocapsídeo por vírion, sendo então denominados SNPV (Single Nuclear Polydrosis Virus), ou vários nucleocapsídeos, os MNPV (Multiple Nuclear Polydrosis Virus) (Bilimoria, 1991). No entanto, os fenótipos S (single) ou M (multiple) não possuem validade taxonômica (Zanotto et al., 1993). Os GVs possuem como característica morfológica a forma ovicilíndrica do seu corpo de oclusão (aqui denominado grânulo), que mede em média 0,3 x 0,5 $\mu \mathrm{m}$ (Crook, 1991) e que possui geralmente um único vírion por grânulo. A proteína responsável pela formação do grânulo é a granulina, que apresenta 53\% de similaridade com a sequência de aminoácidos da poliedrina (Akiyoshi et al., 1985).

\footnotetext{
1 Martignoni ME, Iwai PJ. A catalogue of viral diseases of insects, mites and ticks. In:.Burges HD, Microbial Control of Pests and Plant Diseases 1970-1980.London, UK: Academic Press. 1981. p. 897-911.
} 
Embora a divisão entre estes grupos tenha se fundamentado primeiramente pela morfologia do corpo de oclusão, existem diferenças biológicas significativas entre estes vírus. Os NPVs se replicam no núcleo de células infectadas, enquanto que os GVs podem causar o rompimento precoce da membrana nuclear e continuar sua replicação na região de mistura do citoplasma com o núcleo, ou ainda mais raramente, se replicar no citoplasma de células que aparentemente mantêm seus núcleos intactos (Crook et al., 1997). Outra diferença é que, embora os baculovírus, com algumas exceções, apresentem um limitado espectro de hospedeiro (geralmente uma espécie ou no máximo algumas espécies do mesmo gênero), os GVs são ainda mais específicos e, até hoje, só foram isolados da ordem Lepidoptera (Herniou et al., 2003). Por fim, sabe-se que a maioria dos NPVs infecta os diversos tecidos do hospedeiro (com exceção dos isolados de himenópteros e dípteros). No entanto, os GVs apresentam diferentes restrições de infecção: o granulovírus Cydia pomonella $(\mathrm{CpGV})$ apresenta capacidade de infecção semelhante aos NPVs, enquanto que o granulovírus Trichoplusia ni (TnGV) infecta apenas o tecido gorduroso dos insetos (Hayakawa et al., 1999).

\subsection{O Ciclo de Vida dos Baculovírus}

Os membros da família Baculoviridae produzem, durante o seu ciclo de vida, duas formas distintas de vírus, geneticamente idênticas, mas fenotipicamente diferentes, que desempenham papéis distintos no ciclo viral: os Budded Virus - BVs e os Occlusion-Derived Virus - ODVs, ilustrados na Figura 1. 


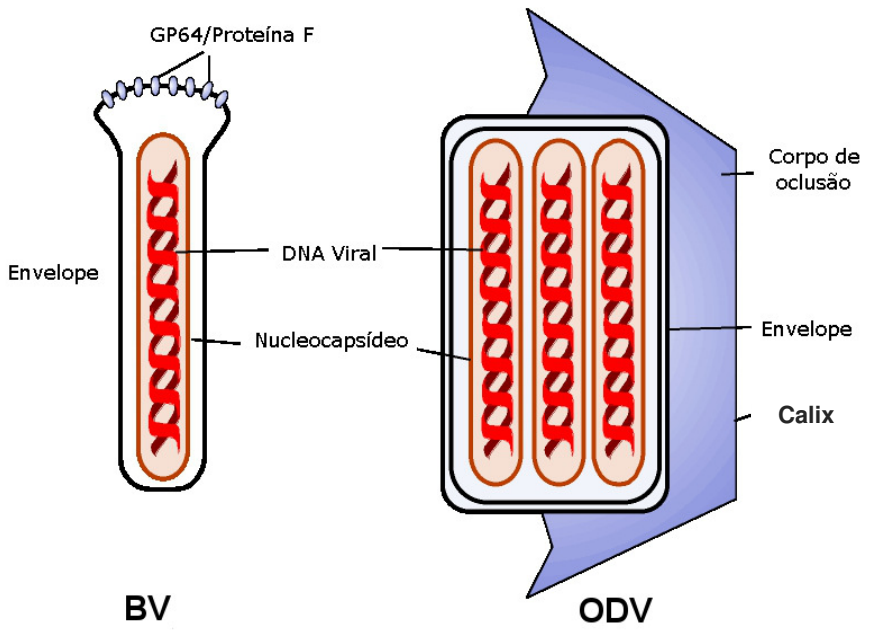

Figura 1. Ilustração dos tipos virais produzidos durante o ciclo de vida dos baculovírus. À esquerda observa-se um BV, onde um único nucleocapsídeo é envolto pela membrana de origem celular, com proteínas virais inseridas (GP64/Proteína F). À direita, um ODV dentro do corpo de oclusão, onde diversas partículas virais são englobadas sob o mesmo envelope (no caso, um vírus do fenótipo M).

FONTE: Adaptada de Kalmakoff e Ward (2003).

O ciclo de vida de um nucleopoliedrovírus (Figura 2) se inicia com a ingestão de poliedros pelas lagartas, que são então dissolvidos no $\mathrm{pH}$ alcalino (em torno de 10) do intestino médio, liberando as partículas virais denominadas ODVs. Os ODVs são os responsáveis pela infecção primária no inseto pois, uma vez liberados no lúmem intestinal, atravessam a membrana peritrófica e penetram nas células colunares do intestino médio, através de fusão de membranas. Tem sido sugerido que sob certas circunstâncias os nucleocapsídeos podem transitar através das células epiteliais e brotar diretamente na hemolinfa ou células traqueais, acelerando assim a infecção e evitando sua eliminação através da perda das células colunares do intestino médio (Washburn et al., 1995). Uma vez dentro das células, os nucleocapsídeos são direcionados ao núcleo através de filamentos de actina, penetrando-o através dos poros nucleares, e quando o DNA viral encontra-se desnudado, é iniciada a transcrição de alguns genes virais com posterior replicação de seu DNA. Após intensa replicação do DNA e transcrição de genes mais tardios, ocorre a montagem de novos nucleocapsídeos. Os nucleocapsídeos recém montados migram para o citoplasma e brotam pela membrana plasmática (já modificada pela inserção de proteínas virais) de forma polarizada, sendo então envelopados individualmente, dando origem as partículas virais denominadas BVs (Blissard e Rohrmann, 1990). Os BVs infectam célula a célula e são os responsáveis pela infecção sistêmica (secundária) dos tecidos da lagarta, que 
segue pelo tecido traqueal, células da hemolinfa, corpo gorduroso, túbulos de Malpighi e células cerebrais (Soares e Ribeiro, 2005). Em estágios mais tardios da infecção ocorre um decaimento do brotamento dos BVs e os nucleocapsídeos começam a se acumular nos núcleos celulares, onde são envelopados em grupos, dando origem aos ODVs. Os ODVs são então oclusos nos poliedros e, com a morte da lagarta, são liberados no meio ambiente, servindo de inóculo para novas infecções. Os corpos de oclusão também podem ser dispersos pelo excremento das lagartas infectadas ou pela ação de predadores (Entwistle et al., 1993; Vasconcelos et al., 1996). Os poliedros são responsáveis pela transmissão do vírus de um inseto a outro e protegem os vírions da degradação e inativação no meio ambiente, principalmente pela radiação ultravioleta (UV) (Granados e Federici, 1986).

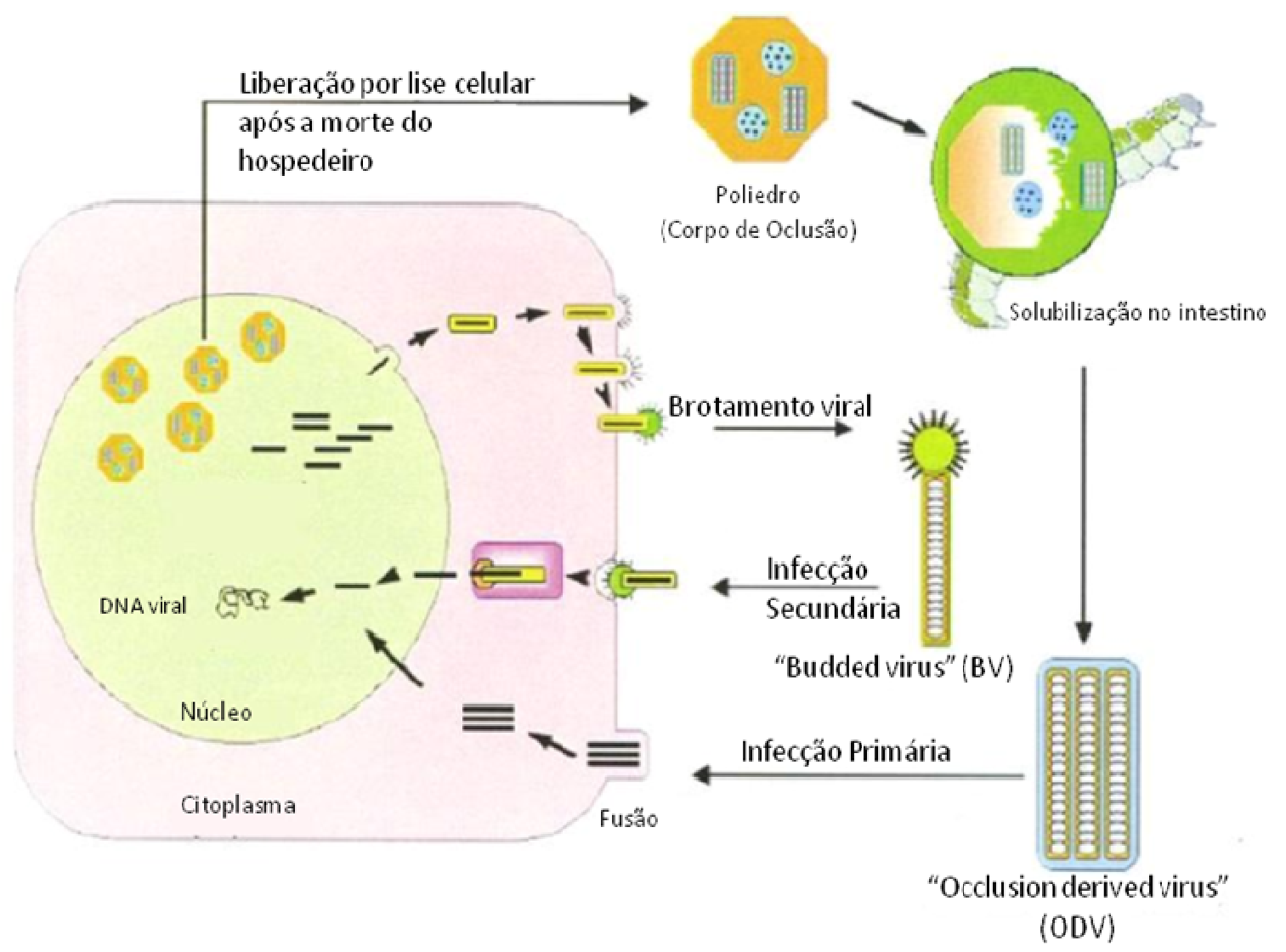

Figura 2. Esquema do ciclo de vida de um nucleopoliedrovírus. O ciclo se inicia pela ingestão de poliedros pela lagarta, com subsequente liberação dos ODVs no lúmem do intestino médio. A infecção primária resulta na produção dos BVs, responsáveis pela infecção secundária dos tecidos da lagarta. Em estágios tardios da infecção, poliedros se acumulam nos núcleos das células infectadas, ocasionando lise nuclear e celular. Com a morte do hospedeiro, os poliedros são liberados no meio ambiente, servindo como inóculo para a infecção de novas lagartas.

FONTE: Adaptada de Ghosh et al. (2002). 


\subsection{Genes Conservados Entre os Baculovírus}

Nos 55 genomas de baculovírus sequenciados até o momento (Tabela em Anexo A), foram identificados 29 genes que estão presentes em todos os vírus, os denominados core genes. Funções já foram postuladas para a maioria destes genes, que podem ser agrupados em cinco categorias funcionais (Tabela 1): (i) replicação do DNA, (ii) transcrição de RNA, (iii) proteínas estruturais, (iv) proteínas auxiliares e (v) proteínas sem função conhecida ou postulada por homologia. Genes relacionados à replicação e transcrição do DNA receberão uma atenção especial mais adiante, juntamente com os genes de função acessória.

Tabela 1 - Genes conservados entre os 55 baculovírus sequenciados até o momento

\begin{tabular}{|c|c|}
\hline Categoria Funcional & $\begin{array}{c}\text { Genes no nucleopoliedrovírus Autographa californica e no } \\
\text { Anticarsia gemmatalis (Ac e Ag) }\end{array}$ \\
\hline Replicação do DNA & $\begin{array}{l}\text { dnapol (Ac65, Ag65), lef-1 (Ac14, Ag19), lef-2 (Ac6, Ag3), } \\
\text { helicase (Ac95, Ag92) }\end{array}$ \\
\hline Transcrição de RNA & $\begin{array}{l}\text { lef-4 (Ac90, Ag87), lef-5 (Ac99, Ag95), lef-8 (Ac50, Ag51), lef- } \\
9 \text { (Ac62, Ag62),p47 (Ac40,Ag44), vlf-1*(Ac77, Ag76) }\end{array}$ \\
\hline $\begin{array}{l}\text { Proteínas } \\
\text { Estruturais }\end{array}$ & $\begin{array}{l}\text { pif-1 (Ac119, Ag117), pif-2 (Ac22, Ag12), gp41 (Ac80, Ag79), } \\
o d v-e 56 \text { (Ac148,Ag144), odv-ec27 (Ac144, Ag140), p6.9 } \\
\text { (Ac100, Ag96), p74 (Ac138, Ag134), vp91 (Ac83, Ag82), vp39 } \\
\text { (Ac89, Ag86), vp1054 (Ac54, Ag55), p33 (Ac92, Ag89) }\end{array}$ \\
\hline Proteínas Auxiliares & alk-exo $(A c 133, A g 129)$ \\
\hline $\begin{array}{l}\text { Proteínas sem } \\
\text { Função Conhecida }\end{array}$ & $\begin{array}{l}38 K(A c 98, A g 94), A c 68 \text { (Ag68), Ac81 (Ag80), Ac96 (Ag93), } \\
\text { Ac109 (Ag107), Ac115 (Ag114), Ac142 (Ag138) }\end{array}$ \\
\hline
\end{tabular}

* também participa do processo de replicação do DNA

Os genes responsáveis pela transcrição de proteínas estruturais estão relacionados com a montagem e oclusão das partículas virais. Entre eles, três codificam a proteínas que formam o nucleocapsídeo: a VP39 (proteína que compõe a maior parte do capsídeo), a VP91 e a VP1054 (Olszewski e Miller, 1997; Russell e Rohrmann, 1997). A GP41 (Whitford e Faulkner, 1992), associada aos vírus oclusos, constitui um tegumento localizado entre o capsídeo e o envelope 
lipoprotéico de origem celular, onde diversas proteínas virais são inseridas. As proteínas P74, PIF-1, PIF-2 estão presentes apenas nos envelope dos ODVs e são essenciais para a infecção oral causada por estas partículas. A ODV-E56 também representa uma proteína estrutural inserida no envelope dos ODVs e parece estar associada à manutenção de sua infectividade oral (Harrison et al., 2010). Não se sabe exatamente a função da proteína P33, mas ela também parece estar associada aos ODVs, dada as análises proteômicas deste fenótipo (Braunagel et al., 2003). A proteína ODV-EC27 está presente nos envelopes de BV e ODV e foi sugerido que ela atue como uma ciclina, regulando o ciclo celular do hospedeiro durante a infecção (Belyavskyi et al., 1998). Outra proteína comum aos BVs e ODVs é a P6.9, uma proteínas básica, que facilita a condensação e o empacotamento do DNA (Wilson et al., 1987).

Embora até o momento nenhuma função específica tenha sido atribuída às proteínas de função desconhecidas ou incertas, elas vêm sendo sistematicamente estudadas, pois provavelmente possuem papéis essenciais na infectividade dos vírus desta família (Chen et al., 2007; Ke et al., 2008; Li et al., 2008a; Vanarsdall et al., 2007). Uma destas proteínas é a 38K, cuja deleção no nucleopoliedrovírus considerado como protótipo da família, o Autographa californica (AcNPV), resultou na inabilidade de produzir novas partículas virais, embora a síntese de DNA tenha ocorrido de maneira semelhante ao AcNPV selvagem (Wu et al., 2006).

\subsection{Transcrição e Regulação dos Genes Virais}

A temporalidade observada no ciclo de vida dos baculovírus é um reflexo de sua regulação gênica, que ocorre ordenadamente e em cascata (O'Reilly et al., 1992). Genes expressos em uma classe temporal regulam a expressão de genes da fase seguinte e, tradicionalmente, os genes são divididos em três classes temporais: (i) precoce (early), (ii) tardia (late ou L) e (iii) muito tardia (very late ou VL).

Genes pertencentes a classe precoce são transcritos pela RNA polimerase RNAdependente II celular (Herniou et al., 2003) e portanto possuem promotores tipicamente eucarióticos, com TATA box e início de transcrição CAGT (Fuchs et al., 1983; Guarino e Smith, 1992a). Genes desta classe ainda podem ser subdividos em immediate early (IE) e delayed early (DE). A expressão dos genes IE independe da síntese de proteínas virais e eles são responsáveis pela transativação dos genes DE. Exemplo de gene da classe IE é o ie-1, que funciona como 
transativador de transcrição (Carson et al., 1991a) e, como será mencionado mais adiante, também atua na replicação do DNA. O gene ie-2 também pertence a esta classe e seu produto gênico também atua como transativador (Theilmann e Stewart, 1992). Genes da classe DE estão relacionados à replicação do DNA viral, como a DNA polimerase (Tomalski et al., 1988), à transcrição, como a RNA polimerase viral (formada pelo produto de quatro genes: lef-4, lef-8, lef9 e p47) (Guarino et al., 1998), aos genes conhecidos como late expression factors (lefs) (Hefferon, 2004) e genes relacionados à modulação celular. A RNA polimerase viral é a responsável pela transcrição dos genes tardios e muito tardios, que só ocorre após o início da replicação do DNA viral. Os promotores tardios reconhecidos por esta polimerase são bem compactos e o motivo do início da transcrição é o TAAG (Passarelli e Guarino, 2007).

A fase tardia (L) compreende os genes expressos após o início da replicação do DNA viral (6 - 18 horas pós-infecção - h p.i.), que possuem principalmente função estrutural e estão relacionados, como já descrito, com a montagem e oclusão das partículas virais (O'Reilly et al., 1992). A fase muito tardia (VL) compreende os genes expressos a partir de $18 \mathrm{~h}$ p.i. Nesta fase são hiper-expressos dois genes estruturais: a poliedrina ( $p o l)$ e a $p 10$, cujos promotores são amplamente utilizados em vetores de expressão de proteínas eucarióticas. A hiper-expressão destes genes parece estar relacionada à sequência de nucleotídeos entre o motivo TAAG e o códon de início de tradução. Esta região é conhecida como sequência burst, pois mutações nesta sequência diminuem enormemente o nível de expressão destes genes, mas não suas temporalidades. Outro fator importante para a hiper-expressão destes genes é a ligação da proteína VLF-1 na região burst (Mistretta e Guarino, 2005).

\subsection{Replicação do DNA Viral}

A replicação dos baculovírus no núcleo das células infectadas resulta na formação de uma estrutura conhecida como estroma virogênico. Esta estrutura é constituída por um material eletro-denso, com inúmeros espaços intra-estromais onde ocorre intensa replicação do DNA viral e montagem dos nucleocapsídeos (Guarino et al., 1992).

Através de ensaios in vitro realizados com o AcNPV (Lu e Miller, 1995a), seis genes virais foram considerados essenciais para a replicação do DNA: (i) lef-1, que codifica a uma primase; (ii) lef-2, que codifica a um fator associado a primase; (iii) helicase; (iv) DNA 
polimerase (dnapol); (v) lef-3, que codifica a uma proteína que se liga a fita simples de DNA (enovelando-o ou desenovelando-o) e que parece estar envolvida no transporte da helicase para o núcleo; e o (vi) ie-1, um transativador transcricional também requerido na replicação (embora ainda não se saiba a função que ele desempenha). Embora a presença destes seis genes seja essencial para a replicação do DNA do AcNPV, apenas os quatro primeiros estão presentes em todos os baculovírus sequenciados até o momento. Além destas proteínas, acredita-se que para a replicação do DNA de baculovírus (assim como em qualquer organismo) são necessárias outras enzimas, como topoisomerases e DNA ligases. Topoisomerases desempenham um papel importante nos processo de desenovelamento e empacotamento de DNA, mas até o momento não foram identificados genes que codifiquem a esta enzima em baculovírus, por isso é sugerido que eles utilizem a topoisomerase celular. Já as DNA ligases são necessárias para ligar os fragmentos de Okasaki produzidos na replicação da fita descontínua, e também é sugerido que os baculovírus utilizem a ligase do hospedeiro, embora todos os granulovírus sequenciados até o momento e dois nucleopoliedrovírus (Lymantria dispar, LdMNPV e Mamestra configurata B, MacoNPV-B) codifiquem genes para esta enzima (Pearson e Rohrmann, 1998).

A replicação do DNA começa em sequências iniciadoras, conhecidas como origem de replicação. Ao contrário de alguns vírus de DNA que utilizam uma única sequência iniciadora, os baculovírus apresentam um padrão mais complexo. Tentativas para identificar a origem de replicação do genoma de baculovírus vêm sendo realizadas desde meados de 1980 (Blinov et al., 1984; Kool et al., 1995; Habib e Hasnain, 2000; Hilton e Winstanley, 2008), e constatou-se que uma gama de sequências não relacionadas pode atuar como iniciadoras de replicação, como por exemplo, as regiões homólogas (homologous regions ou $h r s$ ). As hrs são sequências repetitivas, frequentemente palíndromos imperfeitos de cerca de $30 \mathrm{pb}$, que ocorrem em múltiplas regiões do genoma. Além de servirem como início de replicação do DNA, as hrs também parecem atuar como enhancers na expressão de genes precoces. Além das $h r s$, regiões caracterizadas como non hr sequences e promotores de genes precoces também já foram relacionados como origens de replicação (Wu et al., 1999). Mais recentemente, tem sido sugerido que qualquer região do DNA viral que estiver desenovelada e que permita a entrada do complexo de replicação pode atuar como origem de replicação (Habib e Hasnain, 2000).

Embora ainda não se saiba qual a função desempenhada pelo IE-1 na replicação do DNA, acredita-se que dada a sua capacidade de se ligar às origens de replicação, ele possa atuar como 
um facilitador para a entrada do complexo de replicação. Resumidamente, como ilustrado na Figura 3, acredita-se que este complexo atue da seguinte forma: a helicase viral junto com a topoisomerase celular desenovelam e desanelam o DNA, e os DNAs então em fita simples são estabilizados pelas proteínas LEF-3; isto permite a ação da primase (LEF-1) e de sua proteína acessória (LEF-2), que sintetizam uma curta sequência de oligonucleotídeos que irá servir como template para a ação das DNAs polimerases virais; estas, por processarem apenas no sentido 5'3', irão formar os fragmentos de Okasaki na replicação da fita descontínua (proveniente da fita 5'-3'), que são ligados pela DNA ligase (Rohrmann, 2008).

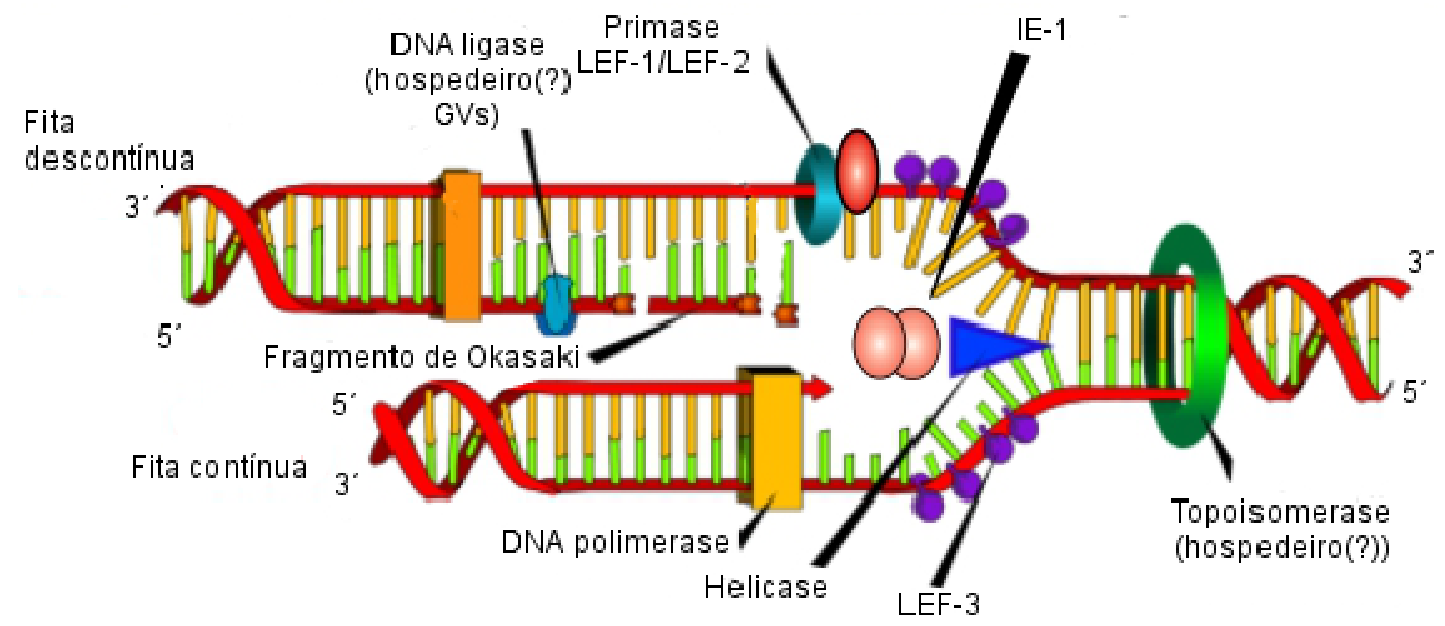

Figura 3. Esquema representando a replicação do DNA de baculovírus e as proteínas (virais e celulares) envolvidas neste processo. A helicase viral e topoisomerase desenovelam e desanelam o DNA, e os DNAs então em fita simples são estabilizados pelas proteínas LEF-3. Isto permite a ação do complexo de primase (LEF-1 e LEF-2), que irão sintetizar uma curta sequência de DNA que servirá como template para a DNA polimerase. Os fragmentos de Okasaki produzidos pela replicação da fita 5'-3'são ligados pela DNA ligase. Embora não se saiba a função do IE-1, ele está representado como um facilitador de entrada para o complexo de replicação.

FONTE: Adaptada de Rohrmann (2008).

O uso de inúmeras origens de replicação é altamente vantajoso pois permite maximizar a quantidade de DNA produzida em um determinado tempo. Entretanto, este fator associado à produção de uma população heterogênea de moléculas de DNA (seja pela ação de nucleases ou pelo desacoplamento precoce do complexo de replicação), exige uma replicação baseada em recombinação para garantir a rápida montagem dos grandes genomas de baculovírus. Assim, nucleases alcalinas (ALK-EXO) associadas ao LEF-3 (Mikhailov et al., 2003) digerem uma pequena região dos DNAs recém duplicados na direção 5' - 3', formando uma cauda de DNA fita 
simples na 3' de cada DNA. Estas caudas de fita simples podem formar híbridos com caudas de sequências homólogas, gerando assim sequências maiores. Por fim, estas moléculas são processadas em genomas maduros, e há evidências que a proteína VLF-1 esteja envolvida neste processo, dada a sua habilidade de se associar a DNAs cruciformes formados durante o processo de recombinação (Okano et al., 2006).

\subsection{A Evolução da Família Baculoviridae}

Os primeiros esforços em inferir a evolução da família Baculoviridae foram baseados em análises filogenéticas envolvendo sequências parciais do gene da poliedrina, proveniente de apenas seis baculovírus (Rohrmann et al., 1981). Em 1993, Zanotto et al. realizaram um estudo filogenético utilizando 12 sequências completas do gene da poliedrina, onde pela primeira vez foi demonstrado que os NPVs se dividem em dois grupos relacionados (Grupo I e II). Com o aumento do conhecimento molecular dos genes de baculovírus e da disponibilidade de novos dados, mais filogenias foram geradas utilizando outros genes, como o egt (Clarke et al., 1996), ou mais recentemente, genes concatenados (Jehle et al., 2006). Entretanto, avanços em sequenciamento de genomas virais vêm possibilitando inferências filogenéticas mais amplas, que além de permitirem a comparação entre as sequências de nucleotídeos e aminoácidos, também permitem comparações sobre conteúdo gênico e sintenia dos genomas (Herniou et al., 2001; Snel et al., 1999). Assim, muitas análises filogenéticas baseadas em genomas completos vêm sendo publicadas, sendo constantemente atualizadas com a disponibilização de novos genomas (Herniou et al., 2001; Oliveira et al., 2006; Wolff et al., 2008; Zanotto e Krakauer, 2008).

Atualmente, 55 genomas de baculovírus já foram sequenciados (Tabela em Anexo A). O Comitê Internacional de Taxonomia de vírus (ICTV) divide esta família em quatro gêneros, classificação suportada pela reconstrução filogenética obtida a partir dos genomas completos: $(i)$ os alfabaculovírus, que compreende os NPVs específicos de lepidópteros, (ii) os betabaculovírus, os GVs específicos de lepidópteros, (iii) os gamabaculovírus, os NPVs específicos de himenópteros e (iv) os deltabaculovírus, os NPVs específicos de dípteros (Figura 4). Estes estudos também corroboram a subdivisão dos NPVs específicos de lepidópteros em Grupo I e II (Zanotto et al., 1993), que possuem como característica biológica distinta o uso de proteínas de fusão de envelope diferentes (Pearson et al., 2000). Os NPVs pertencentes ao Grupo II utilizam a 
proteína de fusão F, enquanto que os NPVs pertencentes ao Grupo I, apesar de também possuírem esta proteína, utilizam a proteína GP64. Foi sugerido que a proteína F seria uma proteína ancestral, substituída em função nos vírus do Grupo I pela GP64, mas que mantém uma importância estrutural nestes vírus (Pearson et al., 2001). O Grupo I ainda pode ser subdividido em duas linhagens: a linhagem no qual faz parte o AcNPV e a linhagem do nucleopoliedrovírus Anticarsia gemmatalis (AgMNPV) (Oliveira et al., 2006). Além disso, através da filogenia, verifica-se a maior similaridade entre os baculovírus que infectam lepidópteras (NPVs e GVs), do que entre os NPVs que infectam ordens diferentes. Este fato talvez seja um reflexo da inabilidade de NPVs que infectam himenóptero e díptero de expandirem a infecção para outros tecidos do hospedeiro, restringindo-a apenas ao intestino médio da lagarta. Entretanto, uma maior amostragem de vírus que infectam estas duas ordens seria necessária para validar esta teoria. 


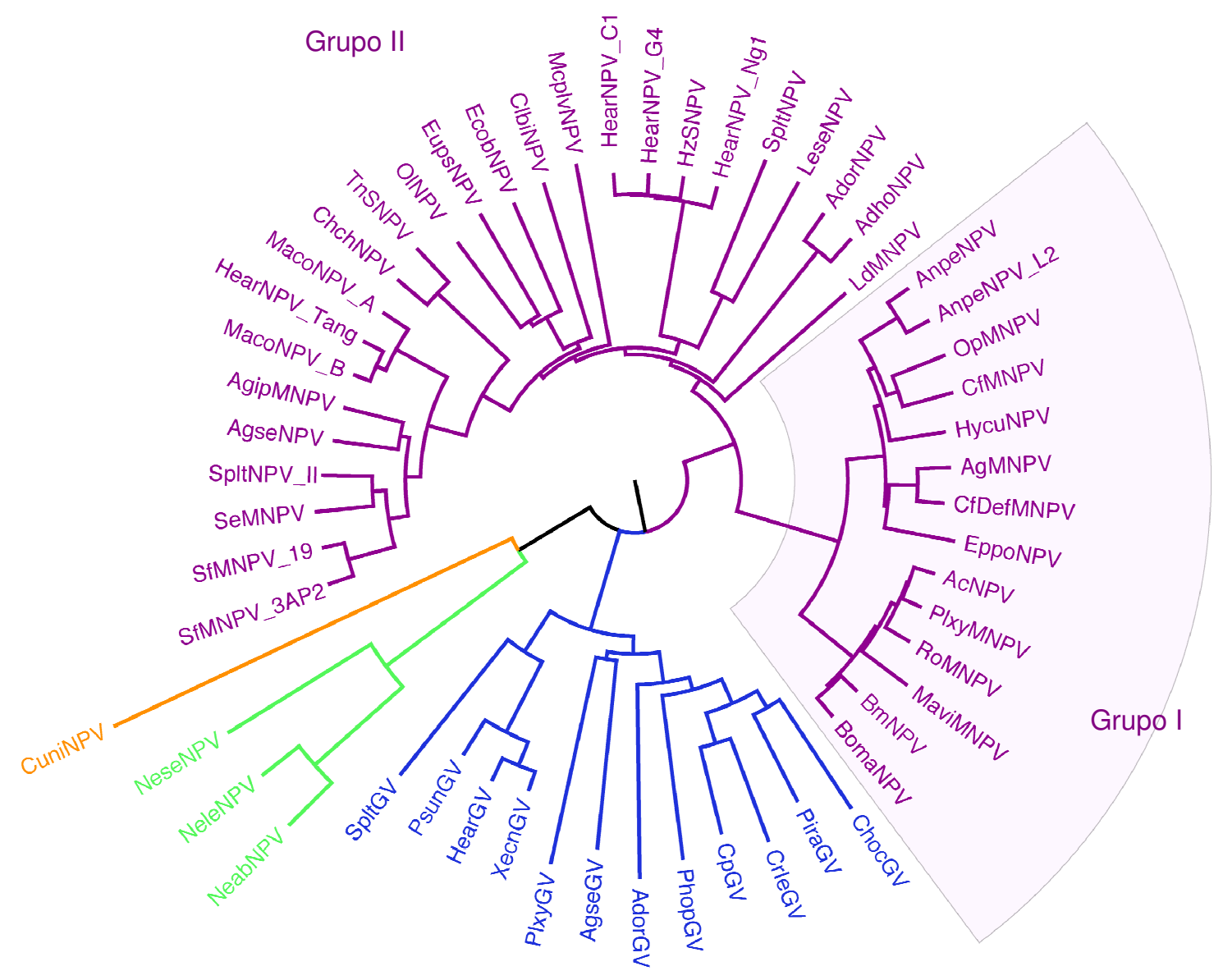

Figura 4. Árvore filogenética que mostra as relações entre os baculovírus cujos genomas foram sequenciados (até o momento). É possível observar a divisão dos baculovírus nos quatros gêneros: (i) alfabaculovírus (em roxo), NPVs específicos de lepidópteros, (ii) betabaculovírus (em azul), GVs específicos de lepidópteros, (iii) gamabaculovírus (em verde), NPVs específicos de himenópteros e (iv) deltabaculovírus (em laranja), NPVs específicos de dípteros. Ainda podemos ver a divisão do NPVs de lepidópteros em Grupo I e Grupo II, e a subdivisão do Grupo I nas linhagens do AcNPV e do AgMNPV.

Embora diversos estudos sejam realizados para avaliar a evolução da família Baculoviridae, poucos levam em conta a co-evolução entre esta família de vírus e seus respectivos hospedeiros. Co-evolução é um dos fatores mais relevantes quando se trata da associação entre patógenos e hospedeiros, e ambos são capazes de se adaptarem em resposta a esta interação. Análises filogenéticas tanto do vírus quanto de seus hospedeiros podem ajudar a elucidar a evolução dos grupos envolvidos, possibilitando a reconstrução da história dos baculovírus. Neste sentido, alguns estudos foram realizados (Rohrmann, 1986; Zanotto et al., 
1993; Federici, 1997; Herniou et al., 2004) e a hipótese mais aceita é de que ancestrais de baculovírus foram transmitidos horizontalmente entre hospedeiros de diferentes ordens, com posterior co-especialização destes baculovírus nas respectivas ordens.

\subsection{Importância Biológica e Econômica da Família Baculoviridae}

Os primeiros registros de infecções causadas por baculovírus são datados do século XVI, quando criadores do bicho-da-seda (Bombyx mori) relataram a liquefação de suas lagartas (Benz, 1986 apud Arif, 2005) $)^{2}$. Com o advento dos primeiros microscópios ópticos, em meados do século XIX, corpos refráteis foram identificados nas amostras provenientes de lagartas doentes, mas a natureza e o significado destes corpos não foram compreendidos até o início do século 20. Von Prowazek, em 1907, foi o primeiro a identificar partículas dentro dos poliedros, mas foi Gratia, em 1939, que durante a dissolução dos poliedros em pH alcalino, sugeriu que estas partículas poderiam ser o agente infeccioso (von Prowazek, 1907 apud Steinhaus, 1963) ${ }^{3}$. Em 1947, com o surgimento da microscopia eletrônica, as partículas virais foram isoladas e identificadas como o agente causador da liquefação das lagartas do bicho-da-seda (Steinhaus, 1963).

Devido a sua alta especificidade, ocorrência natural, fácil manipulação, baixo custo e às diversas pesquisas comprovando que são inofensivos aos vertebrados e plantas (Payne, 1986), os baculovírus vêm sendo utilizados como biopesticidas desde o início do século 20 em países como os Estados Unidos, Canadá, Reino Unido e Brasil. A primeira tentativa em utilizar baculovírus como controle biológico data de 1892, com a introdução do baculovírus Lymantria monacha NPV em florestas de pinheiros na Alemanha (Moscardi, 1999). Em 1913, os Estados Unidos utilizaram o baculovírus Lymantria díspar NPV em florestas, expandindo para aplicações aéreas de baculovírus em plantações de alfafa, na década de 40 . No final da década de 60 , esforços para desenvolver biopesticidas se intensificaram, culminando no registro do primeiro biopesticida viral, o Elcar ${ }^{\mathrm{TM}}$. Este biopesticida era fabricado a partir do nucleopoliedrovírus Helicoverpa zea, e resultou em um eficiente controle contra as espécies de lagarta Helicoverpa e Heliothis (que são muito semelhantes) em plantações de algodão, soja, milho e tomate (Moscardi, 1999). Desde o

\footnotetext{
${ }^{2}$ Benz GA. Introduction: historical perspectives. In: Granados RR, Federici BA (eds.). The biology of baculoviruses. Boca Raton: CRC, 1986. v.1, p.1-35.

${ }^{3}$ von Prowazek, S. Chlamydozoa. II. Gelbsucht dês Seidenraupen. Arch Protistenk. 1997;10:358-364.
} 
Elcar $^{\mathrm{TM}}$, diversos biopesticidas a base de baculovírus foram desenvolvidos, como por exemplo, o GenStar e Spodopterin (ambos utilizados em plantações de algodão), o Gypchek (em florestas de pinhais), o VPN82 (em diversas plantações de vegetais), entre outros. Infelizmente, muitos destes produtos tiveram sua produção descontinuada, sendo os principais motivos: ( $i$ ) o modo de ação lento do produto (o inseto, uma vez infectado, pode demorar até 10 dias para morrer), (ii) o estreito espectro de hospedeiros (muitas plantações apresentam mais de uma praga, que podem não ser susceptíveis ao baculovírus), (iii) dificuldades técnicas e econômicas em produzir in vitro os biopesticidas e, (iv) a resistência dos agricultores em trocar os inseticidas químicos por métodos de controle de pragas mais naturais.

Ao mesmo tempo em que a alta especificidade do baculovírus pode influenciar negativamente seu uso como biopesticida, ela garante a ampla utilização deste vírus como vetor de expressão de proteínas heterólogas. Uma vez que este vírus infecta células de inseto, as proteínas expressas neste sistema sofrem as modificações pós-traducionais típicas de proteínas eucarióticas, como glicolisação, fosforilação, acetilação, metilação, sulfatação, entre outras.

O sistema de expressão baseado em baculovírus possui várias vantagens em relação a outros sistemas. A primeira delas é a presença de promotores fortes em genes não essenciais (como a p10 e a pol), através dos quais se consegue obter uma grande quantidade de proteína. Além disso, os genomas de baculovírus são grandes e por isso comportam grandes fragmentos de DNA (cerca de $20 \mathrm{~Kb}$ ), o que é especialmente importante para genes eucarióticos, que possuem sistemas complexos de splicing. Por fim, são vírus facilmente manipuláveis em laboratório, com culturas de células já bem estabelecidas.

As primeiras proteínas heterólogas expressas em baculovírus foram 'engenheiradas' no AcNPV, como o $\beta$-interferon (Smith et al., 1983) e a interleucina-2 (Smith et al., 1985). Em geral, os baculovírus são utilizados como vetores de expressão de agentes terapêuticos, profiláticos (vacinas) e para diagnósticos (O’Reilly et al., 1992). Recentemente, vêm sendo desenvolvidas ferramentas para uso de baculovírus recombinantes em terapia gênica (Kost e Condreay, 2002; Kost et al., 2005) pois, embora se saiba que baculovírus não se replicam em células de mamíferos, sob determinadas condições eles conseguem penetrar nestas células, sem causar nenhum dano, o que permite seu uso como gene delivery. 


\subsection{O Nucleopoliedrovírus Anticarsia gemmatalis}

O nucleopoliedrovírus Anticarsia gemmatalis (AgMNPV) (Figura 5) foi isolado da lagarta Anticarsia gemmatalis (Lepidoptera: Noctuidae - praga-da-soja), em plantações de soja de Campinas, no ano de 1972 (Allen e Knell, 1977). Para verificar o potencial do uso do AgMNPV como biopesticida, a Empresa Brasileira de Pesquisa e Agropecuária (EMBRAPA) conduziu um programa piloto entre 1980 e 1982. O programa obteve ótimos resultados e já no final de 1982, o AgMNPV começou a ser aplicado em 2.000 hectares de plantação de soja. No final de 1983 este número já havia subido para 20.000 e, em 1990, para um milhão de hectares, tornando-se o programa mundial de maior sucesso que utiliza um vírus como biopesticida.

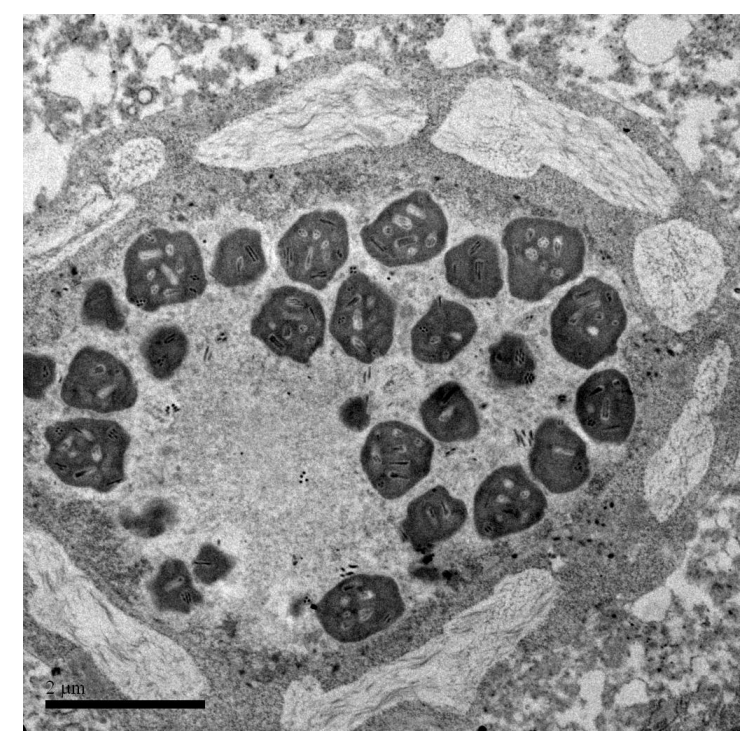

Figura 5. Foto de microscopia eletrônica de uma célula adiposa da lagarta Anticarsia gemmatalis infectada com o AgMNPV. No núcleo celular é possível observar a presença de muitos poliedros, com diversos vírions em seu interior.

FONTE: Foto gentilmente cedida pelo Prof. Bergmann Morais Ribeiro, Prof. Titular do Laboratório de Microscopia Eletrônica e Virologia - Departamento de Biologia Celular (Universidade de Brasília)

Devido à demanda do produto, em 1991, a EMBRAPA estabeleceu acordos com cinco empresas privadas que iniciaram sua produção, comercializando-o com diversos nomes (Baculoviron, Baculovirus Nitral, Coopervirus). Em 2005, o AgMNPV foi utilizado em mais de dois milhões de hectares de plantações de soja (Szewczyk et al., 2006), proporcionando ao país uma economia de milhões de dólares que seriam gastos em agrotóxicos, além dos consideráveis 
benefícios ambientais resultantes da não aplicação de milhões de litros desses produtos (www.embrapa.br).

Infelizmente, desde 2005, a aplicação de AgMNPV em plantações de soja vem diminuindo. Além da resistência natural dos agricultores e ao modo de ação lento do biopesticida, há outros fatores que vêm contribuindo para esta queda. Um importante fator é o aumento da ocorrência de infestações duplas da Anticarsia gemmatalis com a lagarta falsa medideira, Pseudoplusia includens, que não é afetada pelo AgMNPV. Desta forma, os agricultores preferem produtos de espectro de ação mais abrangente, como os pesticidas químicos. Além disso, a empresa Coodetec (fabricante do Coopervirus), responsável pela produção de uma parcela importante do produto comercial deixou de fabricá-lo. Por fim, os descontos que as empresas de pesticidas químicos vêm oferecendo aos agricultores e a falta de apoio para os programas de manejo integrado de pragas consistem em fatores adicionais que contribuem para o decaimento do uso de biopesticidas a base de AgMNPV (Daniel Sosa-Gomez, comunicação pessoal).

Uma recente pesquisa publicada pela Agência Brasil (Empresa Brasil de Comunicação, $2010)^{4}$ mostra que a produção brasileira dos principais grãos (soja, milho, trigo, arroz e feijão) deve crescer $36,7 \%$ até 2020 , com um aumento de quase 10 milhões de hectares de áreas cultiváveis. Aproximadamente 5 milhões de hectares desta expansão serão destinados à produção de soja, com um aumento previsto de $37 \%$ no volume de exportação. Assim, apesar do uso do AgMNPV como agente de controle biológico estar diminuindo gradativamente, sua viabilidade de uso continua grande, dada a expansão do cultivo de soja.

Além de sua importância como agente no controle biológico, o uso do AgMNPV como sistema de expressão para genes e proteínas eucarióticas também deve ser considerado. Como outros membros da família Baculoviridae, o AgMNPV também pode ser utilizado para esta finalidade. Ribeiro et al. (2001) construíram um vírus recombinante (vAgGalA2) contendo o gene para a $\beta$-galactosidase $(\beta$-gal ) sob controle do promotor da poliedrina, obtendo altos níveis de expressão da proteína.

\footnotetext{
${ }^{4}$ Devido à mudança na gestão do portal da Agência Brasil, quando foi feita a revisão desta tese, não foi possível recuperar o artigo original. Como ocorre comumente na internet, os conteúdos são reproduzidos em diversas páginas web, por isso é possível recuperar a notícia em outros domínios, como o http://www.transportabrasil.com.br/2010/03/producao-dos-principais-graos-deve-aumentar-em-quase-50-milhoes-detoneladas-ate-2020.
} 
Dada a sua importância, estudos sobre o AgMNPV são realizados por diversos grupos de pesquisas, em diversos países. Em 1989, Maruniak conduziu um estudo para a identificação e distinção dos diferentes genótipos dos vírus coletados em 1979 (AgNPV-79), determinando como protótipo da espécie o AgMNPV-2D, que representava cerca de 40\% dos isolados obtidos. Em seguida, Johnson e Maruniak (1989) determinaram o mapa físico de seu genoma, através de análises de restrição. Zanotto et al., em 1993, sequenciaram o gene da poliedrina e verificaram a sua similaridade com o gene do nucleopoliedrovírus Orgyia pseudotsugata (OpMNPV). GarciaMaruniak et al. (1996) analisaram e mapearam as primeiras hrs no genoma do AgMNPV. Em 1997, Castro et al. verificaram a suscetibilidade de quatro linhagens celulares de inseto distintos ao AgMNPV, verificando que na linhagem UFL-AG-286 sua infecção foi a mais produtiva, seguida da infecção em IPLB-SF-21 (derivada da lagarta Spodoptera frugiperda), sendo menos eficiente na linhagem IPRI-CF-124T (derivada de Choristoneura fumiferana) e abortiva na linhagem BM-5 (derivada de Bombyx mori). Em 1998, Pombo et al. analisaram as mudanças estruturais na linhagem UFL-AG-286 diante da infecção pelo AgMNPV, verificando a diminuição das projeções celulares, aumento do núcleo e redução da síntese das proteínas celulares. Além disso, vários de seus genes vêm sendo estudados individualmente, como o egt (Rodrigues et al., 2001), gp64 (Pilloff et al., 2003), helicase (de Lima et al., 2004), iap-3 (Carpes et al., 2005) e ie-1 (Bilen et al., 2007). Sua patologia in vivo também foi determinada por Soares et al., em 2005, através do uso de dois recombinates, o AgMNPV com o gene $\beta$-gal (vAgGalA2) e o AgMNPV com o gene $\beta$-gal e com o egt deletado (vAgEGTDelta-lacZ). Além de ter acompanhado a infecção através dos diferentes tecidos do inseto (dado a tonalidade azul induzida pelo produto do gene $\beta$-gal), também se constatou que a infecção era adiantada quando utilizado o vAgEGTDelta-lacZ, sugerindo que biopesticidas a base deste vírus seriam mais eficazes.

Como parte preliminar deste trabalho de Doutorado, o genoma do AgMNPV-2D foi sequenciado (Oliveira et al., 2006) e verificou-se que ele possui 132.242 pares de base (pb), com um conteúdo GC de 44,5\%, valores na média dos encontrados nos demais vírus da família. Foram identificadas 152 fases abertas de leituras (ORFs - Open Read Fame, de no mínimo 50 aminoácidos), sendo que três delas não são encontradas em nenhum outro vírus (Figura 6). Uma destas ORFs (ORF 31) é homóloga a poli (ADP-ribose) polimerase eucariótica (Oliveira et al., 2006; Oliveira et al., 2008), uma enzima nuclear cuja função está associada ao metabolismo de reparo de DNA e ao sistema de apoptose/necrose (D’Amours et al., 1999; Smith, 2001). As 
demais ORFs (63 e 84) não possuem similaridade significativa com outras proteínas depositadas em bancos de dados do National Center for Biotecnhnology Information (NCBI). Das 152 ORFs identificadas no genoma do AgMNPV-2D, somente metade tem função conhecida ou postulada por homologia com fatores descritos em outros sistemas. Assim, trabalhos que tenham como objetivo estudar o padrão de expressão de seus genes poderão ajudar na elucidação das funções de genes desconhecidos e permitirão um maior entendimento da biologia básica do AgMNPV em particular e dos baculovírus em geral. 


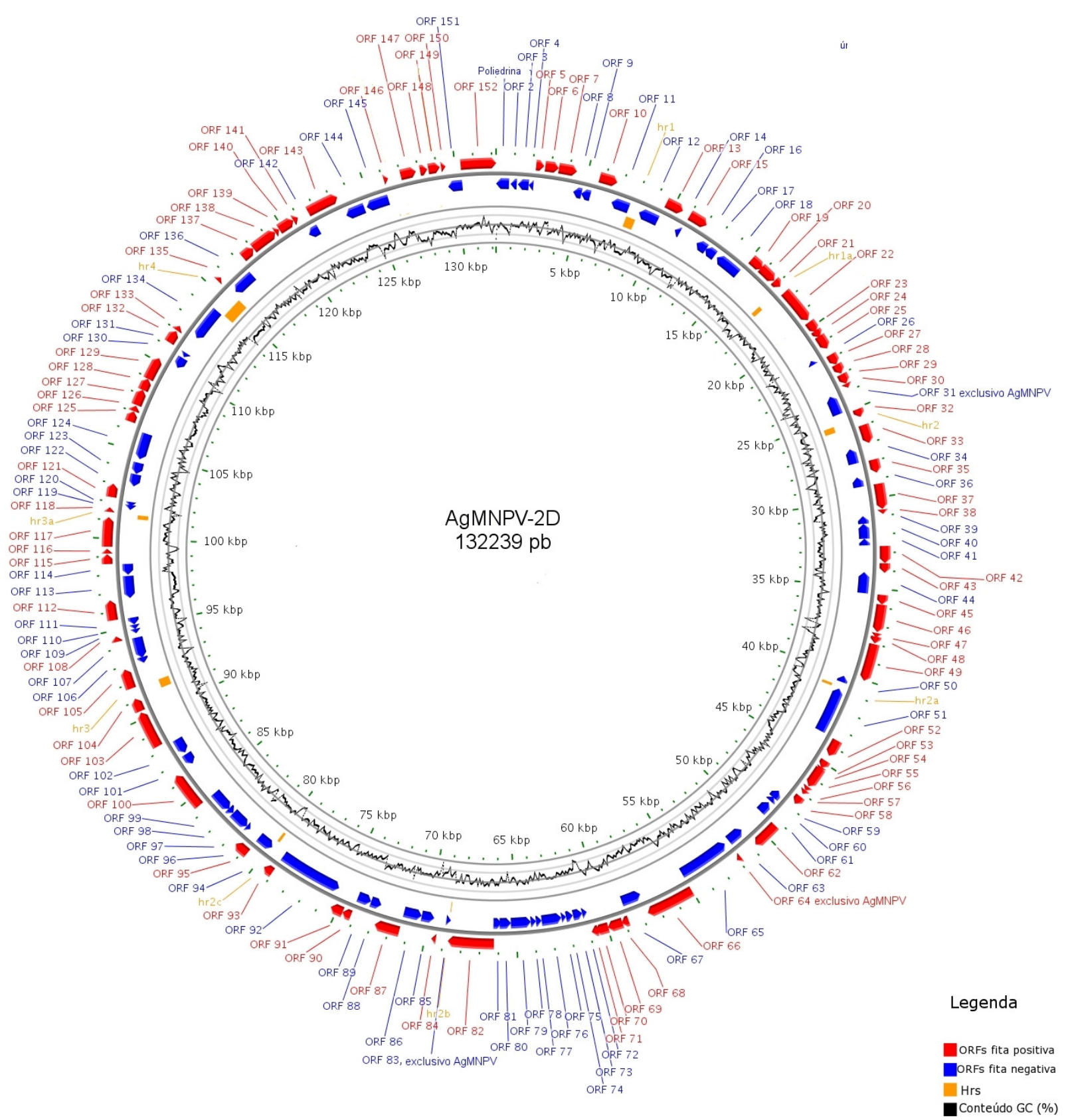

Figura 6. Representação esquemática do genoma do AgMNPV-2D. As setas indicam as ORFs anotadas na fita positiva (em vermelho) e na fita negativa (em azul). As sequências repetitivas ( $h r s)$ estão representadas como retângulos laranja. ORFs 31, 64 e 83 estão denominadas como "exclusivas AgMNPV". O conteúdo GC (em \%) está representado pela linha preta no interior do ciclo. Os picos acima da linha central representam regiões com conteúdo GC maior que $50 \%$.

FONTE: Adaptada de Oliveira et al. (2006). 


\subsection{Análise da Expressão Global dos Genes de Baculovírus: os Transcriptomas}

A expressão temporal de genes virais pode ser determinada por diversas metodologias, entre elas RT-PCR (Reverse Transcription Polymerase Chain Reaction), RNase protection e Northern blot. Com o desenvolvimento de projetos de sequenciamento de genomas virais, metodologias mais abrangentes vêm sendo desenvolvidas para o estudo temporal da expressão de todos os genes, o que é conhecido como transcriptoma. A metodologia mais utilizada para esta finalidade é o microarranjo (microarray), através da qual é possível estudar, ao mesmo tempo, a expressão de centenas de genes, em diferentes condições (Andeweg et al., 2008).

Microarranjos são realizados utilizando-se chips, onde são depositados fragmentos de DNA genômico, cDNAs ou oligonucleotídeos que representam os genes os quais se deseja estudar (probes). Estes DNAs são aplicados ordenadamente em pequenos pontos em lâminas de vidro específicas ou em membranas de nylon por robôs altamente precisos. Muitas empresas já comercializam chips pré-sintetizados para investigar o padrão de expressão de diversos genes, em diversos organismos (inclusive com a finalidade de diagnóstico, como por exemplo, nas empresas Affymetrix e Agilent). Quando se deseja estudar a expressão diferencial em cDNA de diferentes amostras, elas são marcadas com fluoróforos diferentes, geralmente cianina 3 e 5 (Cy 3 e Cy5, respectivamente). As amostras marcadas são hibridizadas com as probes presentes nos chips e em seguida os chips são escaneados com laser, para capturar a fluorescência. A intensidade relativa da combinação da fluorescência das amostras é utilizada para identificar os genes que estão sendo expressos diferentemente nas amostras, sendo hiper- ou hipo-regulados.

Este tipo de abordagem pode ser utilizada para o estudo da expressão diferencial de genes em patologias, como também permite um conhecimento maior da biologia de diversos organismos, em diferentes condições. Em 2003, Yamagishi et al. utilizaram o microarranjo para realizar o primeiro transcriptoma de baculovírus. Neste trabalho, foi analisado o perfil de expressão dos genes do AcNPV, em duas linhagens celulares permissíveis, a IPLB-SF-9 (derivada da lagarta Spodoptera frugiperda) e a TnHigh-Five (Tn-5, derivada da lagarta Trichoplusia $n i$, onde se obtêm altos títulos virais e alta quantidade de proteínas heterólogas recombinantes). Foi identificada a expressão diferenciada de vários genes envolvidos na replicação do DNA e na expressão dos genes tardios, como a p35, um gene anti-apoptótico, que em SF-9 teve uma grande expressão no início da infecção, com decaimento a partir de $3 \mathrm{~h}$ p.i. até 
24h p.i. Na linhagem Tn-5 a p35 foi fracamente expressa até $12 \mathrm{~h}$ p.i., aumentando sua expressão em 24 h p.i. Estes resultados sugerem que a expressão diferencial da $p 35$ e de outros genes seriam responsáveis pela diferença de replicação viral nestes sistemas.

Em 2004, Iwanaga et al. utilizaram a mesma metodologia para verificar o perfil de expressão do AcNPV e do nucleopoliedrovírus Bombyx mori (BmNPV), em linhagens permissíveis e não permissíveis. Estes vírus possuem uma extensa sintenia e similaridade genômica, mas apresentam diferentes espectros de hospedeiros. Assim, ambos os vírus tiveram seu perfil de expressão gênica examinados na linhagem celular BmN (derivada da lagarta Bombyx mori, permissível apenas ao BmNPV) e SF-9 (permissível apenas ao AcNPV), com o intuito de verificar genes ou padrões de expressão que pudessem estar relacionados à permissividade celular. Para o AcNPV verificou-se que a maioria dos genes foram expressos em ambas as linhagens, mas com um atraso de 12 horas na linhagem não permissível. Surpreendentemente, em relação ao nível de expressão, alguns genes de AcNPV foram expressos cerca de duas vezes mais na linhagem não permissível, o que poderia justificar a drástica redução na expressão de pol e p10, corroborada pela inabilidade do AcNPV em formar corpos de oclusão em BmN. Curiosamente, quando foi gerado um AcNPV recombinante contendo a helicase do BmNPV, o AcNPV foi capaz se replicar normalmente nesta linhagem (Maeda et al., 1993). A dinâmica de expressão dos genes de BmNPV em SF-9 revelou um padrão de expressão completamente diferente, com grande redução em praticamente todos os genes, mostrando que a inibição da replicação deste vírus neste sistema provavelmente ocorre ao nível transcricional. Embora até o momento não sejam conhecidos os exatos mecanismos que controlam o espectro de hospedeiros que os baculovírus conseguem infectar, pode-se supor que eles ocorram em diversos níveis, sendo alguns mais gerais, inibindo a transcrição viral como um todo, ou mais específica, como por exemplo, a toxicidade da helicase do AcNPV em BmN.

\subsection{Reação da Polimerase em Cadeia (PCR) em Tempo Real}

Embora análises de expressão temporal diferenciada sejam realizadas por microarranjos, é recomendada a validação dos resultados, principalmente através da técnica de PCR em tempo real (Hess et al., 2001). Este método se baseia na técnica de reação de cadeia da polimerase (PCR) desenvolvida nos anos 80 por Kary Mullis, que permite amplificar fragmentos de DNA em 
mais de milhares de vezes (Saiki et al., 1985). Assim como o PCR revolucionou estudos em biologia molecular, o PCR em tempo real também pode ser considerado uma metodologia revolucionária, pois acopla a sensitividade do PCR e a precisão no monitoramento da geração dos produtos de PCR. Suas aplicações se estendem por diversas áreas, como por exemplo, no diagnóstico de patógenos, sendo um método muito mais rápido e confiável do que as metodologias mais tradicionais (Li et al., 2002a).

A primeira tentativa para desenvolver o PCR em tempo real da forma como o conhecemos hoje foi realizada em 1992. Higuchi et al. (1992) adicionaram a uma reação de PCR comum um corante fluorescente, o brometo de etídeo (EtBr). Desde 1966 já era sabido que a fluorescência do EtBr era aumentada quando o mesmo se encontrava ligado ao DNA (Olmsted e Kearns, 1977). Para mensurar esta fluorescência, o PCR foi realizado sob luz ultravioleta, com o uso de uma vídeo câmera para gravar o acúmulo de DNA. A partir deste primeiro experimento, rapidamente esta metodologia amadureceu e se tornou amplamente comercializada por diferentes companhias, que oferecem diferentes tipos de equipamentos e fluoróforos, menos mutagênicos e mais eficientes que o EtBr. Atualmente, o fluoróforo mais utilizado é o SYBR Green I, que se liga ao sulco menor do DNA emitindo uma fluorescência cerca de 1000 vezes maior do que quando livre em solução (Wittwer et al., 1997). Assim, quanto maior a quantidade de DNA presente em um tubo, maior é a fluorescência emitida pelo SYBR Green. Uma preocupação com o uso deste tipo de fluoróforo se refere a sua capacidade de se ligar a qualquer DNA fita dupla, o que pode interferir no resultado final. Uma forma de se certificar quanto à especificidade do produto é realizar, ao final dos ciclos de amplificação, a curva de dissociação do produto amplificado (curva de melting). Se esta curva apresentar dois ou mais picos, significa que mais de uma sequência foi amplificada.

PCR em tempo real possui diversas vantagens em relação aos demais métodos de quantificação de expressão gênica, sendo 100 mil vezes mais sensível que o RNase protection e mil vezes mais do que hibridizações como Northern blots (Wong e Medrano, 2005). Palmer et al. (2003) mostraram que, quando bem aplicada, a técnica de PCR em tempo real pode detectar menos de uma cópia de RNA de HIV-1 por ml de plasma. Esta sensibilidade é de extrema importância quando a amostra é proveniente, por exemplo, de micro-dissecção. Além disso, PCRs em tempo real são altamente reprodutíveis, relativamente rápidos quando utilizadas algumas automações, e por serem realizados em tubos fechados, são menos vulneráveis a 
contaminação cruzada (como ocorre em microarranjos) (Mackay et al., 2002). Sendo assim, esta é uma metodologia importante e que deve ser considera para o estudo de transcriptomas virais.

\subsection{Métodos para Análises de Transcriptomas}

A informação sobre o desenvolvimento de qualquer organismo encontra-se em seu material genético (genoma). Para que estas informações sejam devidamente utilizadas, elas devem ser convertidas em sequências de aminoácidos, que darão origem às proteínas (proteoma). O fluxo da informação do genoma até o proteoma é intermediado pelo transcriptoma, ou seja, pelas moléculas de RNA mensageiro (RNAm). Assim, a concentração relativa de RNAm de um determinado gene em um organismo pode ser um indicativo do quanto o produto deste gene está sendo utilizado (Kato-Maeda et al., 2001). Como já mencionado, o uso de novas abordagens nos estudos da regulação gênica está permitindo a medição simultânea dos níveis de transcritos de um grande número de genes. Assim, ferramentas de bioinformática vêm sendo desenvolvidas e aplicadas para analisar as centenas de informações provenientes de um único experimento. Desde a publicação do trabalho de Eisen et al. (1998), clusterização (ou agrupamento) de genes de acordo com o perfil de expressão vem sendo uma técnica muito utilizada para agrupar genes que são co-expressos. A hipótese inicial deste tipo de trabalho é que a co-regulação de um grupo de genes implica na similaridade de função nos processos biológicos em que estes genes estão envolvidos. Esta abordagem envolve dois pontos principais: (i) cálculos de distância entre os genes (dissimilaridade) e (ii) algoritmos para realizar o agrupamento dos genes, de acordo com (i).

Métodos para calcular distância entre dois "objetos" (no caso, genes) são inúmeros. O método mais popular é a distância Euclidiana $\left(\mathrm{d}_{\text {eucl }}(\mathrm{X}, \mathrm{Y})\right)$, representada pela equação:

$$
\mathrm{d}_{\text {eucl }}(\mathrm{X}, \mathrm{Y})=\sqrt{\left(\mathrm{x}_{1}-\mathrm{y}_{1}\right)^{2}+\left(\mathrm{x}_{2}-\mathrm{y}_{2}\right)^{2}+\ldots\left(\mathrm{x}_{\mathrm{n}}-\mathrm{y}_{\mathrm{n}}\right)^{2}}
$$

onde para dado gene $\mathrm{X}$ temos as medições dos níveis de expressões temporais $\left(\mathrm{x}_{1}, \mathrm{x}_{2}, \ldots, \mathrm{x}_{\mathrm{n}}\right)$ e para o gene $\mathrm{Y},\left(\mathrm{y}_{1}, \mathrm{y}_{2}, \ldots, \mathrm{y}_{\mathrm{n}}\right)$. A distância Euclidiana leva em consideração a diferença entre o nível de expressão entre dois genes, em um dado tempo amostral (Do e Choi, 2007).

A distância city-block $\left(\mathrm{d}_{\mathrm{city}}(\mathrm{X}, \mathrm{Y})\right)$, também conhecida como distância de Manhattan, é similar à distância Euclidiana, e é representada pela equação: 


$$
\mathrm{d}_{\text {city }}(\mathrm{X}, \mathrm{Y})=\left|\mathrm{x}_{1}-\mathrm{y}_{1}\right|+\left|\mathrm{x}_{2}-\mathrm{y}_{2}\right|+\ldots+\left|\mathrm{x}_{\mathrm{n}}-\mathrm{y}_{\mathrm{n}}\right|
$$

onde para dado gene $\mathrm{X}$ temos as medições dos níveis de expressões temporais $\left(\mathrm{x}_{1}, \mathrm{x}_{2}, \ldots, \mathrm{x}_{\mathrm{n}}\right)$ e para o gene $\mathrm{Y},\left(\mathrm{y}_{1}, \mathrm{y}_{2}, \ldots, \mathrm{y}_{\mathrm{n}}\right)$. Enquanto a distância Euclidiana se baseia na distância mais curta entre dois pontos, a distância de Manhattan representa a soma das distâncias entre cada ponto (Kaufman e Rousseeu, 1990).

Outra métrica de distância muito utilizada é calculada através do coeficiente de correlação de Pearson $(\rho)$, representada pela equação:

$$
\rho=\frac{\sum_{i=1}^{n}\left(x_{i}-\bar{x}\right)\left(y_{i}-\bar{y}\right)}{\sqrt{\sum_{i=1}^{n}\left(x_{i}-\bar{x}\right)^{2}} \sqrt{\sum_{i=1}^{n}\left(y_{i}-\bar{y}\right)^{2}}}
$$

onde $\mathrm{x}_{\mathrm{i}}$ e $\mathrm{y}_{\mathrm{i}}$ são as medidas dos níveis de expressões temporais do gene $\mathrm{X}$ e $\mathrm{Y}$ e $\overline{\mathrm{x}}$ e $\overline{\mathrm{y}}$ representam a média aritmética de todas as medições dos respectivos genes. Ao contrário da distância Euclidiana e de Mahattan, a distância calculada pelo coeficiente de correlação de Pearson representa valores de similaridades entre perfil de expressão, e não entre magnitudes (Do e Choi, 2007). Os valores de coeficiente de correlação de Pearson estão entre -1 e 1 , onde 1 significa que os dois genes possuem perfis de expressão idênticos (correlação perfeita positiva entre as duas variáveis), 0 que os padrões de expressão não possuem qualquer relação linear entre eles, e -1, que representa correlação negativa perfeita entre as duas variáveis (isto é, na mesma proporção que um gene aumenta sua expressão, o outro diminui). Para medir similaridade entre perfis de expressão gênica também podemos utilizar a correlação de Spearman, que pode ser considerada uma versão não-paramétrica do coeficiente de correlação de Pearson, sendo um método mais robusto contra valores discrepantes (Do e Choi, 2007).

Assim como medidas de dissimilaridades gênicas podem ser calculadas por inúmeras maneiras, os métodos de clusterização também são bastante diversificados, sendo que métodos de clusterização hierárquicos aglomerativos são os mais utilizados. Inicialmente estes métodos consideram que cada gene é um grupo, e na primeira interação os dois itens mais próximos são conectados por um ramo. Estes itens são retirados da lista, sendo substituídos por um novo item que representa o ramo recém formado. A distância entre este novo item e os demais é 
recalculada, e novamente os itens mais similares são agrupados. O processo continua até que reste apenas um item na lista. A grande diferença entre as diversas variedades de clusterizações aglomerativas hierárquicas é como as distâncias entre os grupos recém formados e os itens que ainda restam na lista são recalculados. O método mais utilizado é o UPGMA (Unweighted Pair Group Method with Arithmetic Mean), que recalcula a distância entre os novos grupos pela média de todas as dissimilaridades entre os genes dos dois grupos (Kaufman e Rousseeu, 1990; Quinn e Keough, 2002).

Além dos métodos hierárquicos aglomerativos, existem os métodos de clusterização hierárquicos divisivos que, como o próprio nome sugere, funcionam de maneira contrária ao aglomerativo. Estes métodos inicialmente consideram todos os genes como pertencentes ao mesmo grupo, dividindo-o em grupos menores até que cada grupo seja um único gene. Eles são úteis na descrição mais global da hierarquia, pois são menos susceptíveis às etapas inicias de clusterização, ao contrário dos métodos aglomerativos (Kaufman e Rousseeu, 1990; Quinn e Keough, 2002).

Existem também os métodos denominados não-hierárquicos, que não representam a relação entre os objetos de uma forma hierárquica. Um dos algoritmos mais utilizados é o $k$ means que divide os objetos em um número de grupos previamente definido, iniciando com um único objeto por grupo e agrupando os demais objetos que são similares ao primeiro, reavaliando os membros de cada grupo interativamente, minimizando a variância dentro de cada grupo (Jain et al., 1999).

Várias outras metodologias analíticas vêm sendo desenvolvidas ou aplicadas para explorar a informação contida nos dados de expressão gênica. Uma delas é a análise de componente principal (PCA), que reduz a dimensionalidade dos dados transformando-os sucessivamente em set menor (mas informativos) de variáveis (Yeung e Ruzzo, 2001). Escala multidimensional (MDS), que otimiza uma função de stress, também vem sendo utilizada para converter a estrutura da matriz de dissimilaridade em uma representação geométrica. Quanto maior a dissimilaridade entre dois genes, mais distantes eles estarão representados graficamente (Taguchi e Oono, 2005).

Além das clusterizações, análises genômicas em larga escala também podem resultar na modelagem de redes gênicas regulatórias (Gene Regulatory Network - GRN). Uma GRN simula de maneira gráfica a dependências entre os genes e seus produtos, representando-os em uma rede 
composta de nós (os genes e /ou proteínas) e arestas (as interações moleculares entre os nós). Muitas metodologias para modelagem de GRNs utilizam informações sobre o nível dos transcritos que, implicitamente, podem capturar os eventos regulatórios em nível protéico (Hecker et al., 2009). Conhecimentos funcionais a cerca dos produtos gênicos também são utilizados, como por exemplo, através das anotações pelo Gene Ontology (GO), que organiza as informações de uma forma hierárquica, definindo grupos de genes com funções biológicas em comum. 


\section{CONCLUSÃO}

Neste trabalho objetivamos estudar o AgMNPV-2D por duas perspectivas diferentes: a viral, analisando a expressão temporal de seus genes em duas linhagens celulares (UFL-AG e SF-9); e a celular, analisando o padrão de expressão diferencial de genes da linhagem UFL-AG infectadas com o AgMNPV-2D. As principais conclusões foram:

(i) A maioria das ORFs foi expressa em ambas as linhagens celulares, sem que pudéssemos detectar um padrão nas diferenças entre os perfis temporais; entretanto, em relação aos níveis de expressão, podemos observar que a maioria dos genes apresentou-se mais expresso na linhagem UFL-AG;

(ii) Genes parálogos apresentaram padrões de expressão distintos, o que pode ser um indicativo de diferentes funções desempenhadas por cada cópia;

(iii) A replicação precoce do DNA de AgMNPV pode justificar o perfil de expressão precoce encontrado neste trabalho, além da sensitividade da metodologia utilizada;

(iv) A escolha da métrica de distância em estudos de transcriptomas interfere mais no resultado final do que a técnica de clusterização;

(v) $\mathrm{O}$ agrupamento dos genes por $k$-means segue em sua maioria a hora pós-infecção onde a expressão de cada gene foi detectada, o que é coerente com a expressão gênica em cascata típica de baculovírus;

(vi) Parece não ser válida, para baculovírus, a predição de função gênica para genes poucos caracterizados considerando-se a função de genes que agrupam próximos, em experimentos de expressão;

(vii) A GRN de baculovírus possivelmente possui poucos nós basais com alta conectividade (hubs) gerando uma GRN em ondas em formato de estrela, com redundância funcional; 
(viii) Em 20h p.i. já ocorreu uma grande inibição da transcrição celular e uma grande diversidade de genes e funções foram hipo-reguladas. 


\section{REFERÊNCIAS $^{* t}$}

Acharya A, Gopinathan KP. Characterization of late gene expression factors lef- 9 and lef- 8 from Bombyx mori nucleopolyhedrovirus. J Gen Virol. 2002;83:2015-2023.

Adams MD, Celniker SE, Holt RA, Evans CA, Gocayne JD, Amanatides PG, Scherer SE, Li PW, Hoskins RA, Galle RF, George RA, Lewis SE, Richards S, Ashburner M, Henderson SN, Sutton GG, Wortman JR, Yandell MD, Zhang Q, Chen LX, Brandon RC, Rogers YHC, Blazej RG, Champe M, Pfeiffer BD, Wan KH, Doyle C, Baxter EG, Helt G, Nelson CR, Miklos GLG, Abril JF, Agbayani A, An HJ, Andrews-Pfannkoch C, Baldwin D, Ballew RM, Basu A, Baxendale J, Bayraktaroglu L, Beasley EM, Beeson KY, Benos PV, Berman BP, Bhandari D, Bolshakov S, Borkova D, Botchan MR, Bouck J, Brokstein P, Brottier P, Burtis KC, Busam DA, Butler H, Cadieu E, Center A, Chandra I, Cherry JM, Cawley S, Dahlke C, Davenport LB, Davies A, de Pablos B, Delcher A, Deng ZM, Mays AD, Dew I, Dietz SM, Dodson K, Doup LE, Downes M, Dugan-Rocha S, Dunkov BC, Dunn P, Durbin KJ, Evangelista CC, Ferraz C, Ferriera S, Fleischmann W, Fosler C, Gabrielian AE, Garg NS, Gelbart WM, Glasser K, Glodek A, Gong FC, Gorrell JH, Gu ZP, Guan P, Harris M, Harris NL, Harvey D, Heiman TJ, Hernandez JR, Houck J, Hostin D, Houston DA, Howland TJ, Wei MH, Ibegwam C, Jalali M, Kalush F, Karpen GH, Ke ZX, Kennison JA, Ketchum KA, Kimmel BE, Kodira CD, Kraft C, Kravitz S, Kulp D, Lai ZW, Lasko P, Lei YD, Levitsky AA, Li JY, Li ZY, Liang Y, Lin XY, Liu XJ, Mattei B, McIntosh TC, McLeod MP, McPherson D, Merkulov G, Milshina NV, Mobarry C, Morris J, Moshrefi A, Mount SM, Moy M, Murphy B, Murphy L, Muzny DM, Nelson DL, Nelson DR, Nelson KA, Nixon K, Nusskern DR, Pacleb JM, Palazzolo M, Pittman GS, Pan S, Pollard J, Puri V, Reese MG, Reinert K, Remington K, Saunders RDC, Scheeler F, Shen H, Shue BC, SidenKiamos I, Simpson M, Skupski MP, Smith T, Spier E, Spradling AC, Stapleton M, Strong R, Sun E, Svirskas R, Tector C, Turner R, Venter E, Wang AHH, Wang X, Wang ZY, Wassarman DA, Weinstock GM, Weissenbach J, Williams SM, Woodage T, Worley KC, Wu D, Yang S, Yao QA, Ye J, Yeh RF, Zaveri JS, Zhan M, Zhang GG, Zhao Q, Zheng LS, Zheng XQH, Zhong FN, Zhong WY, Zhou XJ, Zhu SP, Zhu XH, Smith HO, Gibbs RA, Myers EW, Rubin GM, Venter JC. The genome sequence of drosophila melanogaster. Science. 2000;287(5461):2185-2195.

Afonso CL, Tulman ER, Lu Z, Balinsky CA, Moser BA, Becnel JJ, Rock DL, Kutish GF. Genome sequence of a baculovirus pathogenic for Culex nigripalpus. $J$ Virol. 2001;75(22):11157-11165.

\footnotetext{
* De acordo com: International Committee of Medical Journal Editors. Uniform requirements for manuscripts submitted to Biomedical Journal: sample references. Available from: http://www.icmje.org [2007 May 22]
} 
Ahrens CH, Rohrmann GF. Replication of Orgyia pseudotsugata baculovirus DNA: Lef-2 and ie1 are essential and ie-2, p34, and op-iap are stimulatory genes. Virology. 1995;212(2):650-662.

Ahrens CH, Russell RL, Funk CJ, Evans JT, Harwood SH, Rohrmann GF. The sequence of the Orgyia pseudotsugata multinucleocapsid nuclear polyhedrosis virus genome. Virology. 1997;229(2):381-399.

Akiyoshi D, Chakerian R, Rohrmann GF, Nesson MH, Beaudreau GS. Cloning and sequencing of the granulin gene from the Trichoplusia ni granulosis-virus. Virology. 1985;141(2):328-332.

Alfonso P, Rivera J, Hernaez B, Alonso C, Escribano JM. Identification of cellular proteins modified in response to african swine fever virus infection by proteomics. Proteomics. 2004;4(7):2037-2046.

Allen GE, Knell JD. A nuclear polyhedrosis virus of Anticarsia gemmatalis: I, ultrastructure, replication, and pathogenicity. The Florida Entomologist. 1977;60233-240.

Altschul SF, Gish W, Miller W, Myers EW, Lipman DJ. Basic local alignment search tool. J Mol Biol. 1990;215(3):403-410.

Andeweg AC, Haagmans BL, Osterhaus AD. Virogenomics: The virus-host interaction revisited. Curr Opin Microbiol. 2008;11(5):461-466.

Arif BM. A brief journey with insect viruses with emphasis on baculoviruses. J Invertebr Pathol. 2005;89(1):39-45.

Ayres MD, Howard SC, Kuzio J, Lopez-Ferber M, Possee RD. The complete DNA sequence of Autographa californica nuclear polyhedrosis virus. Virology. 1994;202(2):586-605.

Bassemir U, Miltenburger HG, David P. Morphogenesis of nuclear polyhedrosis-virus from Autographa californica in a cell-line from Mamestra-brassicae (cabbage moth) - further aspects on baculovirus assembly. Cell Tissue Res. 1983;228(3):587-595.

Becker D, Knebel-Morsdorf D. Sequence and temporal appearance of the early transcribed baculovirus gene he65. J Virol. 1993;67(10):5867-5872. 
Belaich MN, Rodriguez VA, Bilen MF, Pilloff MG, Romanowski V, Sciocco-Cap A, Ghiringhelli PD. Sequencing and characterisation of p74 gene in two isolates of Anticarsia gemmatalis MNPV. Virus Genes. 2006;32(1):59-70.

Belyavskyi M, Braunagel SC, Summers MD. The structural protein odv-ec27 of Autographa californica nucleopolyhedrovirus is a multifunctional viral cyclin. Proc Natl Acad Sci USA. 1998;95(19):11205-11210.

Bendtsen JD, Nielsen H, von Heijne G, Brunak S. Improved prediction of signal peptides: Signalp 3.0. J Mol Biol. 2004;340(4):783-795.

Beniya H, Braunagel SC, Summers MD. Autographa californica nuclear polyhedrosis virus: Subcellular localization and protein trafficking of bv/odv-e26 to intranuclear membranes and viral envelopes. Virology. 1998;240(1):64-75.

Benson G. Tandem repeats finder: A program to analyze DNA sequences. Nucleic Acids Res. 1999;27(2):573-580.

Bilen MF, Pilloff MG, Belaich MN, Da Ros VG, Rodrigues JC, Ribeiro BM, Romanowski V, Lozano ME, Ghiringhelli PD. Functional and structural characterisation of AgMNPV iel. Virus Genes. 2007;35(3):549-562.

Bilimoria SL. The biology of nuclear polyhedrosis viruses. In: Kurtak E, editor. Viurses of invertebrates. New Yorl: Marcel Dekker; 1991.p. 1-72.

Bilimoria SL, Demirbag Z, Ng H. Host-specific transcription of baculovirus genes. SAAS Bull Biochem Biotechnol. 1993;61-7.

Bilimoria SL, Demirbag Z, NG H, Reinisch AJ. Abortive cell culture of nuclear polyhedrosis viruses as model systems for host specificity. Pesq Agrop Bras. 1992;27123-141.

Blissard GW, Rohrmann GF. Baculovirus diversity and molecular biology. Annu Rev Entomol. 1990;35127-155.

Blinov VM, Gutorov VV, Holodilov NG, Iljichev AA, Karginov VA, Mikrjukov NN, Mordvinov VA, Nikonov IV, Petrov NA, Urmanov IH, Vasilenko SK. Nucleotide-sequence of the Galleria- 
mellonella nuclear polyhedrosis-virus origin of DNA-replication. Febs Lett. 1984;167(2):254258.

Bonning BC, Hammock BD. Development of recombinant baculoviruses for insect control. Annu Rev Entomol. 1996;41191-210.

Braunagel SC, Elton DM, Ma H, Summers MD. Identification and analysis of an Autographa californica nuclear polyhedrosis virus structural protein of the occlusion-derived virus envelope: Odv-e56. Virology. 1996b;217(1):97-110.

Braunagel SC, He H, Ramamurthy P, Summers MD. Transcription, translation, and cellular localization of three Autographa californica nuclear polyhedrosis virus structural proteins: Odve18, odv-e35, and odv-ec27. Virology. 1996a;222(1):100-114.

Braunagel SC, Parr R, Belyavskyi M, Summers MD. Autographa californica nucleopolyhedrovirus infection results in sf9 cell cycle arrest at $\mathrm{G}(2) / \mathrm{M}$ phase. Virology. 1998;244(1):195-211.

Braunagel SC, Russell WK, Rosas-Acosta G, Russell DH, Summers MD. Determination of the protein composition of the occlusion-derived virus of Autographa californica nucleopolyhedrovirus. Proc Natl Acad Sci USA. 2003;100(17):9797-9802.

Bruno WJ, Socci ND, Halpern AL. Weighted neighbor joining: A likelihood-based approach to distance-based phylogeny reconstruction. Mol Biol Evol. 2000;17(1):189-197.

Bulet P, Stocklin R, Menin L. Anti-microbial peptides: From invertebrates to vertebrates. Immunol Rev. 2004;198169-184.

Burma S, Mukherjee B, Jain A, Habib S, Hasnain SE. An unusual 30-kda protein binding to the polyhedrin gene promoter of Autographa californica nuclear polyhedrosis virus. J Biol Chem. 1994;269(4):2750-2757.

Carpentier DC, Griffiths CM, King LA. The baculovirus p10 protein of Autographa californica nucleopolyhedrovirus forms two distinct cytoskeletal-like structures and associates with polyhedral occlusion bodies during infection. Virology. 2008;371(2):278-291. 
Carpes MP, de Castro ME, Soares EF, Villela AG, Pinedo FJ, Ribeiro BM. The inhibitor of apoptosis gene (iap-3) of Anticarsia gemmatalis multicapsid nucleopolyhedrovirus (agmnpv) encodes a functional iap. Arch Virol. 2005;150(8):1549-1562.

Carson DD, Summers MD, Guarino LA. Transient expression of the Autographa californica nuclear polyhedrosis virus immediate-early gene, ie-n, is regulated by three viral elements. $\mathrm{J}$ Virol. 1991a;65(2):945-951.

Carson DD, Summers MD, Guarino LA. Molecular analysis of a baculovirus regulatory gene. Virology. 1991b;182(1):279-286.

Carstens EB, Liu JJ, Dominy C. Identification and molecular characterization of the baculovirus cfmnpv early genes: ie-1, ie-2 and pe38. Virus Res. 2002;83(1-2):13-30.

Carstens EB, Lu AL, Chan HL. Sequence, transcriptional mapping, and overexpression of p47, a baculovirus gene regulating late gene expression. J Virol. 1993;67(5):2513-2520.

Castro ME, Souza ML, Araujo S, Bilimoria SL. Replication of Anticarsia gemmatalis nuclear polyhedrosis virus in four lepidopteran cell lines. J Invertebr Pathol. 1997;69(1):40-45.

Castro ME, Souza ML, Bilimoria SL. Host-specific transcription of nucleopolyhedrovirus gene homologues in productive and abortive Anticarsia gemmatalis MNPV infections. Arch Virol. 1999;144(6):1111-1121.

Charlton CA, Volkman LE. Sequential rearrangement and nuclear polymerization of actin in baculovirus-infected Spodoptera frugiperda cells. J Virol. 1991;65(3):1219-1227.

Chen CJ, Thiem SM. Differential infectivity of two Autographa californica nucleopolyhedrovirus mutants on three permissive cell lines is the result of lef-7 deletion. Virology. 1997;227(1):88-95.

Chen HQ, Chen KP, Yao Q, Guo ZJ, Wang LL. Characterization of a late gene, orf67 from Bombyx mori nucleopolyhedrovirus. FEBS Lett. 2007;581(30):5836-5842.

Chen X, WF IJ, Tarchini R, Sun X, Sandbrink H, Wang H, Peters S, Zuidema D, Lankhorst RK, Vlak JM, $\mathrm{Hu} \mathrm{Z}$. The sequence of the Helicoverpa armigera single nucleocapsid nucleopolyhedrovirus genome. J Gen Virol. 2001;82:241-257. 
Chen X, Zhang WJ, Wong J, Chun G, Lu A, McCutchen BF, Presnail JK, Herrmann R, Dolan M, Tingey $\mathrm{S}, \mathrm{Hu} \mathrm{ZH}$, Vlak JM. Comparative analysis of the complete genome sequences of Helicoverpa zea and Helicoverpa armigera single-nucleocapsid nucleopolyhedroviruses. J Gen Virol. 2002;83:673-684.

Chen YR, Wu CY, Lee ST, Wu YJ, Lo CF, Tsai MF, Wang CH. Genomic and host range studies of Maruca vitrata nucleopolyhedrovirus. J Gen Virol. 2008;89:2315-2330.

Clarke EE, Tristem M, Cory JS, O'Reilly DR. Characterization of the ecdysteroid udpglucosyltransferase gene from Mamestra brassicae nucleopolyhedrovirus. J Gen Virol. 1996;77:2865-2871.

Cook D, Swayne DF. Interactive and dynamic graphics for data analysis. Gentleman R, editor. New York: Springer-Verlag; 2007.188p.

Crook NE. Baculoviridae: Sub-group b: Comparative aspects of granulosis viruses. In: Kurstak E, editor. Viruses of invertebrates. New York: Marcel Dekker; 1991. p.73-110.

Crook NE, Clem RJ, Miller LK. An apoptosis-inhibiting baculovirus gene with a zinc finger-like motif. J Virol. 1993;67(4):2168-2174.

Crook NE, James JD, Smith IR, Winstanley D. Comprehensive physical map of the Cydia pomonella granulovirus genome and sequence analysis of the granulin gene region. J Gen Virol. 1997;78:965-974.

D'Amours D, Desnoyers S, D'Silva I, Poirier GG. Poly(adp-ribosyl)ation reactions in the regulation of nuclear functions. Biochem J. 1999;342:249-268.

Datta S, Datta S. Comparisons and validation of statistical clustering techniques for microarray gene expression data. Bioinformatics. 2003;19(4):459-466.

de Jong JG, Lauzon HA, Dominy C, Poloumienko A, Carstens EB, Arif BM, Krell PJ. Analysis of the Choristoneura fumiferana nucleopolyhedrovirus genome. J Gen Virol. 2005;86:929-943.

de Lima L, Pinedo FJ, Ribeiro BM, Zanotto PMA, Wolff JL. Identification, expression and phylogenetic analysis of the Anticarsia gemmatalis multicapsid nucleopolyhedrovirus (AgMNPV) helicase gene. Virus Genes. 2004;29(3):345-352. 
Deng F, Wang R, Fang M, Jiang Y, Xu X, Wang H, Chen X, Arif BM, Guo L, Hu Z. Proteomics analysis of Helicoverpa armigera single nucleocapsid nucleopolyhedrovirus identified two new occlusion-derived virus-associated proteins, ha44 and ha100. J Virol. 2007;81(17):9377-9385.

Do JH, Choi D-K. Clustering approaches to identifying gene expression patterns from DNA microarray data. Molecules and Cells. 2007;251-10.

Duffy SP, Young AM, Morin B, Lucarotti CJ, Koop BF, Levin DB. Sequence analysis and organization of the Neodiprion abietis nucleopolyhedrovirus genome. J Virol. 2006;80(14):69526963.

Durantel D, Croizier G, Ravallec M, Lopez-Ferber M. Temporal expression of the AcMNPV lef4 gene and subcellular localization of the protein. Virology. 1998a;241(2):276-284.

Durantel D, Croizier L, Ayres MD, Croizier G, Possee RD, Lopez-Ferber M. The pnk/pnl gene (orf 86) of Autographa californica nucleopolyhedrovirus is a non-essential, immediate early gene. J Gen Virol. 1998b;79:629-637.

Durham AM, Kashiwabara AY, Matsunaga FT, Ahagon PH, Rainone F, Varuzza L, Gruber A. Egene: A configurable pipeline generation system for automated sequence analysis. Bioinformatics. 2005;21(12):2812-2813.

Eisen MB, Spellman PT, Brown PO, Botstein D. Cluster analysis and display of genome-wide expression patterns. Proc Natl Acad Sci USA. 1998;95(25):14863-14868.

Eldridge R, Li Y, Miller LK. Characterization of a baculovirus gene encoding a small conotoxinlike polypeptide. J Virol. 1992;66(11):6563-6571.

Empresa Brasil de Comunicação. Pesquisa realizada pela Assessoria de Gestão Estratégica do Ministério da Agricultura, Pecuária e Abastecimento, publicada em 04 de março de 2010. Disponível em http://agenciabrasil.ebc.com.br.

Entwistle PF, Forkner AC, Green BM, Cory JS. Avian dispersal of nuclear polyhedrosis viruses after induced epizootics in the pine beauty moth, panolis flammea (lepidoptera: Noctuidae). Biological Control. 1993;3(1):61-69. 
Escasa SR, Lauzon HA, Mathur AC, Krell PJ, Arif BM. Sequence analysis of the Choristoneura occidentalis granulovirus genome. J Gen Virol. 2006;87:1917-1933.

Evans OP, O'Reilly D R. Purification and kinetic analysis of a baculovirus ecdysteroid udpglucosyltransferase. Biochem J. 1998;332:807-808.

Fan Q, Li SY, Wang LM, Zhang B, Ye B, Zhao ZJ, Cui LW. The genome sequence of the multinucleocapsid nucleopolyhedrovirus of the chinese oak silkworm Antheraea pernyi. Virology. 2007;366(2):304-315.

Fan TJ, Han LH, Cong RS, Liang J. Caspase family proteases and apoptosis. Acta Biochim Biophys Sin. 2005;37(11):719-727.

Fan X, McLachlin JR, Weaver RF. Identification and characterization of a protein kinaseinteracting protein encoded by the Autographa californica nuclear polyhedrosis virus. Virology. 1998;240(2):175-182.

Federici BA. Baculovirus pathogenesis. In: Miller LK, editor. The baculoviruses. New York: Plenum Press; 1997. p. 33-56.

Freeman M. Rhomboid proteases and their biological functions. Annu Rev Genet. 2008;42191210.

Friesen PD, Miller LK. Temporal regulation of baculovirus rna: Overlapping early and late transcripts. J Virol. 1985;54(2):392-400.

Friesen PD, Miller LK. The regulation of baculovirus gene-expression. Curr Top Microbiol. 1986;131:31-49.

Fuchs LY, Woods MS, Weaver RF. Viral transcription during Autographa californica nuclear polyhedrosis virus infection: A novel rna polymerase induced in infected Spodoptera frugiperda cells. J Virol. 1983;48(3):641-646.

Galiana-Arnoux D, Dostert C, Schneemann A, Hoffmann JA, Imler JL. Essential function in vivo for dicer-2 in host defense against rna viruses in Drosophila. Nat Immunol. 2006;7(6):590-597. 
Garcia-Maruniak A, Pavan OH, Maruniak JE. A variable region of Anticarsia gemmatalis nuclear polyhedrosis virus contains tandemly repeated DNA sequences. Virus Res. 1996; 41 (2): 123132.

Garcia-Maruniak A, Maruniak JE, Zanotto PM, Doumbouya AE, Liu JC, Merritt TM, Lanoie JS. Sequence analysis of the genome of the Neodiprion sertifer nucleopolyhedrovirus. J Virol. 2004;78(13):7036-7051.

Ghosh S, Parvez MK, Banerjee K, Sarin SK, Hasnain SE. Baculovirus as mammalian cell expression vector for gene therapy: An emerging strategy. Mol Ther. 2002;6(1):5-11.

Giannopoulos PN, Nassoury N, Lamontagne L, Guertin C, Rashidan KK. Choristoneura fumiferana granulovirus pk-1: A baculoviral protein kinase. $\mathrm{J}$ Biochem Mol Biol. 2005;38(4):457-467.

Girard PA, Boublik Y, Wheat CW, Volkoff AN, Cousserans F, Brehelin M, Escoubas JM. X-tox: An atypical defensin derived family of immune-related proteins specific to lepidoptera. Dev Comp Immunol. 2008;32(5):575-584.

Goenka S, Weaver RF. The p26 gene of the Autographa californica nucleopolyhedrovirus: Timing of transcription, and cellular localization and dimerization of product. Virus Res. 2008;131(2):136-144.

Gomi S, Majima K, Maeda S. Sequence analysis of the genome of Bombyx mori nucleopolyhedrovirus. J Gen Virol. 1999;801323-1337.

Granados RR, Federici BA. The biology of baculoviruses. Inc CP, editor. Boca Raton, Florida,1986.

Gross CH, Shuman S. Characterization of a baculovirus-encoded RNA 5'-triphosphatase. J Virol. 1998;72(9):7057-7063.

Guarino LA, Dong W, Xu B, Broussard DR, Davis RW, Jarvis DL. Baculovirus phosphoprotein pp31 is associated with virogenic stroma. J Virol. 1992b;66(12):7113-7120.

Guarino LA, Mistretta TA, Dong W. Baculovirus lef-12 is not required for viral replication. J Virol. 2002b;76(23):12032-12043. 
Guarino LA, Smith M. Regulation of delayed-early gene transcription by dual tata boxes. J Virol. 1992a;66(6):3733-3739.

Guarino LA, Summers MD. Nucleotide sequence and temporal expression of a baculovirus regulatory gene. J Virol. 1987;61(7):2091-2099.

Guarino LA, Xu B, Jin J, Dong W. A virus-encoded rna polymerase purified from baculovirusinfected cells. J Virol. 1998;72(10):7985-7991.

Gutierrez S, Kikhno I, Lopez Ferber M. Transcription and promoter analysis of pif, an essential but low-expressed baculovirus gene. J Gen Virol. 2004;85(Pt 2):331-341.

Habib S, Hasnain SE. Differential activity of two non-hr origins during replication of the baculovirus Autographa californica nuclear polyhedrosis virus genome. J Virol. 2000;74(11):5182-5189.

Hansen IA, Meyer SR, Schafer I, Scheller K. Interaction of the anterior fat body protein with the hexamerin receptor in the blowfly calliphora vicina. Eur J Biochem. 2002;269(3):954-960.

Harrison RL. Genomic sequence analysis of the illinois strain of the Agrotis ipsilon multiple nucleopolyhedrovirus. Virus Genes. 2009;38(1):155-170.

Harrison RL, Bonning BC. Comparative analysis of the genomes of Rachiplusia ou and Autographa californica multiple nucleopolyhedroviruses. J Gen Virol. 2003;84:1827-1842.

Harrison RL, Lynn DE. Genomic sequence analysis of a nucleopolyhedrovirus isolated from the diamondback moth, Plutella xylostella. Virus Genes. 2007;35(3):857-873.

Harrison RL, Popham HJ. Genomic sequence analysis of a granulovirus isolated from the old world bollworm, Helicoverpa armigera. Virus Genes. 2008a;36(3):565-581.

Harrison RL, Puttler B, Popham HJ. Genomic sequence analysis of a fast-killing isolate of Spodoptera frugiperda multiple nucleopolyhedrovirus. J Gen Virol. 2008b;89:775-790.

Harrison RL, Sparks WO, Bonning BC. The Autographa californica multiple nucleopolyhedrovirus odv-e56 envelope protein is required for oral infectivity and can be 
functionally substituted by the Rachiplusia ou multiple nucleopolyhedrovirus odv-e56. J Gen Virol. 2010; 91:1173-82

Harrison RL, Summers MD. Biosynthesis and localization of the Autographa californica nuclear polyhedrosis virus 25k gene product. Virology. 1995;208(1):279-288.

Hashimoto Y, Hayakawa T, Ueno Y, Fujita T, Sano Y, Matsumoto T. Sequence analysis of the Plutella xylostella granulovirus genome. Virology. 2000;275(2):358-372.

Hayakawa T, Ko R, Okano K, Seong SI, Goto C, Maeda S. Sequence analysis of the Xestia cnigrum granulovirus genome. Virology. 1999;262(2):277-297.

Hawtin RE, Arnold K, Ayres MD, Zanotto PMA, Howard SC, Gooday GW, Chappell LH, Kitts PA, King LA, Possee RD. Identification and preliminary characterization of a chitinase gene in the Autographa californica nuclear polyhedrosis virus genome. Virology. 1995;212(2):673-685.

Hayakawa T, Ko R, Okano K, Seong SI, Goto C, Maeda S. Sequence analysis of the Xestia cnigrum granulovirus genome. Virology. 1999;262(2):277-297.

Hecker M, Lambeck S, Toepfer S, van Someren E, Guthke R. Gene regulatory network inference: Data integration in dynamic models-a review. Biosystems. 2009;96(1):86-103.

Hefferon KL. Baculovirus late expression factors. J Mol Microbiol Biotechnol. 2004;7(3):89101.

Herniou EA, Luque T, Chen X, Vlak JM, Winstanley D, Cory JS, O'Reilly DR. Use of whole genome sequence data to infer baculovirus phylogeny. J Virol. 2001;75(17):8117-8126.

Herniou EA, Olszewski JA, Cory JS, O'Reilly DR. The genome sequence and evolution of baculoviruses. Annu Rev Entomol. 2003;48:211-234.

Herniou EA, Olszewski JA, O'Reilly DR, Cory JS. Ancient coevolution of baculoviruses and their insect hosts. J Virol. 2004;78(7):3244-3251.

Hess KR, Zhang W, Baggerly KA, Stivers DN, Coombes KR. Microarrays: Handling the deluge of data and extracting reliable information. Trends Biotechnol. 2001;19(11):463-468. 
Higuchi R, Dollinger G, Walsh PS, Griffith R. Simultaneous amplification and detection of specific DNA sequences. Biotechnology. 1992;10(4):413-417.

Hilton S, Winstanley D. The origins of replication of granuloviruses. Arch Virol. 2008a;153(8):1527-1535.

Hilton S, Winstanley D. Genomic sequence and biological characterization of a nucleopolyhedrovirus isolated from the summer fruit tortrix, Adoxophyes orana. J Gen Virol. 2008b;89:2898-2908.

Hu Z, Mellor J, Wu J, DeLisi C. Visant: An online visualization and analysis tool for biological interaction data. BMC Bioinformatics. 2004;5(17)1-8.

Huang X, Madan A. Cap3: A DNA sequence assembly program. Genome Res. 1999;9(9):868877.

Hughes AL. Evolution of inhibitors of apoptosis in baculoviruses and their insect hosts infection, Genetics ans Evolution. 2002;2(1):3-10.

Hyink O, Dellow RA, Olsen MJ, Caradoc-Davies KM, Drake K, Herniou EA, Cory JS, O'Reilly DR, Ward VK. Whole genome analysis of the Epiphyas postvittana nucleopolyhedrovirus. J Gen Virol. 2002;83:957-971.

IJkel W, van Strien EA, Heldens JG, Broer R, Zuidema D, Goldbach RW, Vlak JM. Sequence and organization of the Spodoptera exigua multicapsid nucleopolyhedrovirus genome. J Gen Virol. 1999;80:3289-3304.

Ikeda M, Shikata M, Shirata N, Chaeychomsri S, Kobayashi M. Gene organization and complete sequence of the Hyphantria cunea nucleopolyhedrovirus genome. J Gen Virol. 2006;87:25492562.

Ikeda M, Yanagimoto K, Kobayashi M. Identification and functional analysis of Hyphantria cunea nucleopolyhedrovirus iap genes. Virology. 2004;321(2):359-371.

Iwanaga M, Takaya K, Katsuma S, Ote M, Tanaka S, Kamita SG, Kang W, Shimada T, Kobayashi M. Expression profiling of baculovirus genes in permissive and nonpermissive cell lines. Biochem Biophys Res Commun. 2004;323(2):599-614. 
Iwanaga M, Shimada T, Kobayashi M, Kang W. Identification of differentially expressed host genes in Bombyx mori nucleopolyhedrovirus infected cells by using subtractive hybridization. Appl Entomol Zool. 2007; 42 (1): 151-159.

Jain AK, Murty MN, Flynn PJ. Data clustering: A review. Acm Comput Surv. 1999;31(3):264323.

Jakubowska AK, Peters SA, Ziemnicka J, Vlak JM, van Oers MM. Genome sequence of an enhancin gene-rich nucleopolyhedrovirus (npv) from agrotis segetum: Collinearity with spodoptera exigua multiple npv. J Gen Virol. 2006;87(Pt 3):537-551.

Jehle JA, Lange M, Wang HL, Hu ZH, Wang YJ, Hauschild W. Molecular identification and phylogenetic analysis of baculoviruses from lepidoptera. Virology. 2006;346(1):180-193.

Johnson DW, Maruniak JE. Physical map of Anticarsia-gemmatalis nuclear polyhedrosis-virus (AgMNPV-2) DNA. J Gen Virol. 1989;70:1877-1883.

Jiang SS, Chang IS, Huang LW, Chen PC, Wen CC, Liu SC, Chien LC, Lin CY, Hsiung CA, Juang JL. Temporal transcription program of recombinant Autographa californica multiple nucleopolyhedrosis virus. J Virol. 2006;80(18):8989-8999.

Kall L, Krogh A, Sonnhammer ELL. A combined transmembrane topology and signal peptide prediction method. J Mol Biol. 2004;338(5):1027-1036.

Kalmakoff J, Ward UK. Baculoviruses. Avaiable from http://www.microbiologybytes.com/virology/kalmakoff/baculo [17/06/2010].

Kato-Maeda M, Gao Q, Small PM. Microarray analysis of pathogens and their interaction with hosts. Cell Microbiol. 2001;3(11):713-719.

Katsuma S, Shimada T, Kobayashi M. Characterization of the baculovirus Bombyx mori nucleopolyhedrovirus gene homologous to the mammalian fgf gene family. Virus Genes. 2004;29(2):211-217.

Kaufman L, RousseeuW PJ. Finding groups in data: An introduction to cluster analysis. New Jersey: Jonh Wiley \& Sons; 1990. 
Ke J, Wang J, Deng R, Wang X. Autographa californica multiple nucleopolyhedrovirus ac66 is required for the efficient egress of nucleocapsids from the nucleus, general synthesis of preoccluded virions and occlusion body formation. Virology. 2008;374(2):421-431.

Kim D, Weaver RF. Transcription mapping and functional analysis of the protein tyrosine/serine phosphatase (ptpase) gene of the Autographa californica nuclear polyhedrosis virus. Virology. 1993;195(2):587-595.

King LA, Possee RD. The baculovirus expression system: A laboratory guide. Oxford: Chapman \& Hall; 1992.

Klotman ME, Chang TL. Defensins in innate antiviral immunity. Nat Rev Immunol. 2006;6(6):447-456.

Knebel-Morsdorf D, Kremer A, Jahnel F. Baculovirus gene me53, which contains a putative zinc finger motif, is one of the major early-transcribed genes. J Virol. 1993;67(2):753-758.

Kool M, Ahrens CH, Vlak JM, Rohrmann GF. Replication of baculovirus DNA. J Gen Virol. 1995;76:2103-2118.

Kost TA, Condreay JP. Recombinant baculoviruses as mammalian cell gene-delivery vectors. Trends Biotechnol. 2002;20(4):173-180.

Kost TA, Condreay JP, Jarvis DL. Baculovirus as versatile vectors for protein expression in insect and mammalian cells. Nat Biotechnol. 2005;23(5):567-575.

Krogh A, Larsson B, von Heijne G, Sonnhammer ELL. Predicting transmembrane protein topology with a hidden markov model: Application to complete genomes. J Mol Biol. 2001;305(3):567-580.

Kuzio J, Pearson MN, Harwood SH, Funk CJ, Evans JT, Slavicek JM, Rohrmann GF. Sequence and analysis of the genome of a baculovirus pathogenic for Lymantria dispar. Virology. 1999;253(1):17-34.

LaCount DJ, Friesen PD. Role of early and late replication events in induction of apoptosis by baculoviruses. J Virol. 1997;71(2):1530-1537. 
Lange M, Jehle JA. The genome of the Cryptophlebia leucotreta granulovirus. Virology. 2003;317(2):220-236.

Lapointe R, Back DW, Ding Q, Carstens EB. Identification and molecular characterization of the Choristoneura fumiferana multicapsid nucleopolyhedrovirus genomic region encoding the regulatory genes pkip, p47, lef-12, and gta. Virology. 2000;271(1):109-121.

Lauzon HA, Jamieson PB, Krell PJ, Arif BM. Gene organization and sequencing of the Choristoneura fumiferana defective nucleopolyhedrovirus genome. J Gen Virol. 2005;86:945961.

Lauzon HA, Lucarotti CJ, Krell PJ, Feng Q, Retnakaran A, Arif BM. Sequence and organization of the Neodiprion lecontei nucleopolyhedrovirus genome. J Virol. 2004;78(13):7023-7035.

Lauzon HAM, Garcia-Maruniak A, Zanotto PMA, Clemente JC, Herniou EA, Lucarotti CJ, Arif BM, Maruniak JE. Genomic comparison of Neodiprion sertifer and Neodiprion lecontei nucleopolyhedroviruses and identification of potential hymenopteran baculovirus-specific open reading frames. J Gen Virol. 2006;87:1477-1489.

Li G, Wang J, Deng R, Wang X. Characterization of AcMNPV with a deletion of ac68 gene. Virus Genes. 2008a;37(1):119-127.

Li L, Donly C, Li Q, Willis LG, Keddie BA, Erlandson MA, Theilmann DA. Identification and genomic analysis of a second species of nucleopolyhedrovirus isolated from Mamestra configurata. Virology. 2002b;297(2):226-244.

Li L, Rohrmann GF. Characterization of a baculovirus alkaline nuclease. J Virol. 2000;74(14):6401-6407.

Li Q, Donly C, Li L, Willis LG, Theilmann DA, Erlandson M. Sequence and organization of the Mamestra configurata nucleopolyhedrovirus genome. Virology. 2002a;294(1):106-121.

Li X, Lauzon HA, Sohi SS, Palli SR, Retnakaran A, Arif BM. Molecular analysis of the p48 gene of Choristoneura fumiferana multicapsid nucleopolyhedroviruses CfMNPV and CfDefNPV. J Gen Virol. 1999;80:1833-1840. 
Li Y, Guarino LA. Roles of lef-4 and PTP/BVP rna triphosphatases in processing of baculovirus late mrnas. J Virol. 2008b;82(11):5573-5583.

Li YH, Passarelli AL, Miller LK. Identification, sequence, and transcriptional mapping of lef-3, a baculovirus gene involved in late and very late gene-expression. J Virol. 1993;67(9):5260-5268.

Li Z, Li C, Pan L, Yu M, Yang K, Pang Y. Characterization of p24 gene of Spodoptera litura multicapsid nucleopolyhedrovirus. Virus Genes. 2005;30(3):349-356.

Li Z, Pan L, Yu H, Li S, Zhang G, Pang Y. Identification and characterization of odv-e25 of Spodoptera litura multicapsid nucleopolyhedrovirus. Virus Genes. 2006;32(1):13-19.

Li Z, Yokoi S, Kawamura Y, Maeda S, Ezaki T, Deguchi T. Rapid detection of quinolone resistance-associated gyra mutations in neisseria gonorrhoeae with a lightcycler. J Infect Chemother. 2002;8(2):145-150.

Lin G, Blissard GW. Analysis of an Autographa californica multicapsid nucleopolyhedrovirus lef-6-null virus: Lef-6 is not essential for viral replication but appears to accelerate late gene transcription. J Virol. 2002;76(11):5503-5514.

Lin G, Slack JM, Blissard GW. Expression and localization of lef-11 in Autographa californica nucleopolyhedrovirus-infected sf9 cells. J Gen Virol. 2001;82(Pt 9):2289-2294.

Lin X, Chen Y, Yi Y, Yan J, Zhang Z. Promoter analysis of Bombyx mori nucleopolyhedrovirus ubiquitin gene. J Microbiol. 2008;46(4):429-435.

Liu HS, Bilimoria SL. Infected cell specific protein and viral-DNA synthesis in productive and abortive infections of Spodoptera frugiperda nuclear polyhedrosis-virus. Arch Virol. 1990;115:101-113.

Liu JJ, Carstens EB. Identification, localization, transcription, and sequence analysis of the Choristoneura fumiferana nuclear polyhedrosis virus DNA polymerase gene. Virology. 1995;209(2):538-549.

Lloyd RE. Translational control by viral proteinases. Virus Res. 2006;119(1):76-88. 
Lu A, Carstens EB. Transcription analysis of the ecori d region of the baculovirus Autographa californica nuclear polyhedrosis virus identifies an early 4-kilobase rna encoding the essential p143 gene. J Virol. 1992;66(2):655-663.

Lu A, Miller LK. The roles of eighteen baculovirus late expression factor genes in transcription and DNA replication. J Virol. 1995a;69(2):975-982.

Lu A, Miller LK. Differential requirements for baculovirus late expression factor genes in 2 celllines. J Virol. 1995b;69(10):6265-6272.

Lu M, Iatrou K. Characterization of a domain of the genome of BmNPV containing a functional gene for a small capsid protein and harboring deletions eliminating three open reading frames that are present in acnpv. Gene. 1997;185(1):69-75.

Luckow VA, Lee SC, Barry GF, Olins PO. Efficient generation of infectious recombinant baculoviruses by site-specific transposon-mediated insertion of foreign genes into a baculovirus genome propagated in Escherichia coli. J Virol. 1993;67(8):4566-4579.

Luque T, Finch R, Crook N, O'Reilly DR, Winstanley D. The complete sequence of the Cydia pomonella granulovirus genome. J Gen Virol. 2001;82:2531-2547.

Ma SW, Corsaro BG, Klebba PE, Fraser MJ. Cloning and sequence analysis of a p40 structural protein gene of Helicoverpa zea nuclear polyhedrosis virus. Virology. 1993;192(1):224-233.

Ma XC, Shang JY, Yang ZN, Bao YY, Xiao Q, Zhang CX. Genome sequence and organization of a nucleopolyhedrovirus that infects the tea looper caterpillar, Ectropis obliqua. Virology. 2007;360(1):235-246.

Mackay IM, Arden KE, Nitsche A. Real-time pcr in virology. Nucleic Acids Res. 2002;30(6):1292-1305.

Maddison DR, Maddison WP. Macclade. Analysis of phylogeny and character evolution. Sunderland, Massachusetts: Sinauer Associates; 1992.

Maeda S, Kamita SG, Kondo A. Host range expansion of Autographa californica nuclear polyhedrosis virus (npv) following recombination of a 0.6-kilobase-pair DNA fragment originating from bombyx mori npv. J Virol. 1993;67(10):6234-6238. 
Mainprize TH, Lee K, Miller LK. Variation in the temporal expression of overlapping baculovirus transcripts. Virus Res. 1986;6(1):85-99.

Marchler-Bauer A, Panchenko AR, Shoemaker BA, Thiessen PA, Geer LY, Bryant SH. Cdd: A database of conserved domain alignments with links to domain three-dimensional structure. Nucleic Acids Res. 2002;30(1):281-283.

Marques JT, Carthew RW. A call to arms: Coevolution of animal viruses and host innate immune responses. Trends Genet. 2007;23(7):359-364.

Maruniak JE. Molecular-biology of Anticarsia gemmatalis baculovirus. Mem I Oswaldo Cruz. 1989; 84 107-111

Maruniak JE, Garcia-Maruniak A, Souza ML, Zanotto PMA, Moscardi F. Physical maps and virulence of Anticarsia gemmatalis nucleopolyhedrovirus genomic variants. Arch Virol. 1999;144(10):1991-2006.

Maxwell KL, Frappier L. Viral proteomics. Microbiol Mol Biol R. 2007;71(2):398-+.

Mayer MP, Bukau B. Hsp70 chaperones: Cellular functions and molecular mechanism. Cell Mol Life Sci. 2005;62(6):670-684.

McLachlin JR, Miller LK. Identification and characterization of vlf-1, a baculovirus gene involved in very late gene expression. J Virol. 1994;68(12):7746-7756.

Mikhailov VS, Okano K, Rohrmann GF. Baculovirus alkaline nuclease possesses a 5'-->3' exonuclease activity and associates with the DNA-binding protein lef-3. J Virol. 2003;77(4):2436-2444.

Milks ML, Washburn JO, Willis LG, Volkman LE, Theilmann DA. Deletion of pe38 attenuates AcMNPV genome replication, budded virus production, and virulence in Heliothis virescens. Virology. 2003;310(2):224-234.

Mistretta TA, Guarino LA. Transcriptional activity of baculovirus very late factor 1. J Virol. 2005;79(3):1958-1960. 
Moore RC, Purugganan MD. The early stages of duplicate gene evolution. Proc Natl Acad Sci USA. 2003;100(26):15682-15687.

Morris TD, Miller LK. Promoter influence on baculovirus-mediated gene-expression in permissive and nonpermissive insect cell-lines. J Virol. 1992;66(12):7397-7405.

Moscardi F. Assessment of the application of baculoviruses for control of lepidoptera. Annu Rev Entomol. 1999;44:257-289.

Moulos P, Papadodima O, Chatziioannou A, Loutrari H, Roussos C, Kolisis FN. A transcriptomic computational analysis of mastic oil-treated lewis lung carcinomas reveals molecular mechanisms targeting tumor cell growth and survival. BMC Med Genomics. 2009;2:68.

Muller J, Szklarczyk D, Julien P, Letunic I, Roth A, Kuhn M, Powell S, von Mering C, Doerks T, Jensen LJ, Bork P. Eggnog v2.0: Extending the evolutionary genealogy of genes with enhanced non-supervised orthologous groups, species and functional annotations. Nucleic Acids Res. 2009;38:190-195.

Muller R, Pearson MN, Russell RL, Rohrmann GF. A capsid-associated protein of the multicapsid nuclear polyhedrosis virus of Orgyia pseudotsugata: Genetic location, sequence, transcriptional mapping, and immunocytochemical characterization. Virology. 1990;176(1):133144.

Mygind PH, Fischer RL, Schnorr KM, Hansen MT, Sonksen CP, Ludvigsen S, Raventos D, Buskov S, Christensen B, De Maria L, Taboureau O, Yaver D, Elvig-Jorgensen SG, Sorensen MV, Christensen BE, Kjaerulff S, Frimodt-Moller N, Lehrer RI, Zasloff M, Kristensen HH. Plectasin is a peptide antibiotic with therapeutic potential from a saprophytic fungus. Nature. 2005;437(7061):975-980.

Nakai M, Goto C, Kang W, Shikata M, Luque T, Kunimi Y. Genome sequence and organization of a nucleopolyhedrovirus isolated from the smaller tea tortrix, Adoxophyes honmai. Virology. 2003;316(1):171-183.

Nakajima Y, Natori S. Identification and characterization of an anterior fat body protein in an insect. J Biochem. 2000;127(5):901-908. 
Nie ZM, Zhang ZF, Wang D, He PA, Jiang CY, Song L, Chen F, Xu J, Yang L, Yu LL, Chen J, Lv ZB, Lu JJ, Wu XF, Zhang YZ. Complete sequence and organization of Antheraea pernyi nucleopolyhedrovirus, a dr-rich baculovirus. BMC Genomics. 2007;8248.

Nobiron I, O'Reilly D, Olzewski JA. Autographa californica nucleopolyhedrovirus infection of spodoptera frugiperda cells: A global analysis of host gene regulation during infection, using a differential display approach. J Gen Virol. 2003;84:3029-3039.

O'Reilly DR, Miller LK, Luckow VA. Baculovirus expression vectors: A laboratory manual. Salt Lake City.1992.

Ogembo JG, Caoili BL, Shikata M, Chaeychomsri S, Kobayashi M, Ikeda M. Comparative genomic sequence analysis of novel Helicoverpa armigera nucleopolyhedrovirus (NPV) isolated from kenya and three other previously sequenced Helicoverpa spp. NPVs. Virus Genes. 2009;39:261-272.

Ohkawa T, Rowe AR, Volkman LE. Identification of six Autographa californica multicapsid nucleopolyhedrovirus early genes that mediate nuclear localization of g-actin. J Virol. 2002;76(23):12281-12289.

Okano K, Mikhailov VS, Maeda S. Colocalization of baculovirus ie-1 and two DNA-binding proteins, dbp and lef-3, to viral replication factories. J Virol. 1999;73(1):110-119.

Okano K, Vanarsdall AL, Mikhailov VS, Rohrmann GF. Conserved molecular systems of the baculoviridae. Virology. 2006;344(1):77-87.

Oliveira JVC, de Melo FL, Romano CM, Iamarino A, Rizzi TS, Yeda FP, Harsi CM, Wolff JLC, Zanotto PMA. Structural and phylogenetic relationship of ORF 31 from the Anticarsia gemmatalis MNPV to poly (adp-ribose) polymerases (PARP). Virus Genes. 2008;37(2):177-184.

Oliveira JVC, Wolff JL, Garcia-Maruniak A, Ribeiro BM, de Castro ME, de Souza ML, Moscardi F, Maruniak JE, Zanotto PMA. Genome of the most widely used viral biopesticide: Anticarsia gemmatalis multiple nucleopolyhedrovirus. J Gen Virol. 2006;87:3233-3250.

Olmsted J 3rd, Kearns DR. Mechanism of ethidium bromide fluorescence enhancement on binding to nucleic acids. Biochemistry-Us. 1977;16(16):3647-3654. 
Olszewski J, Miller LK. Identification and characterization of a baculovirus structural protein, vp1054, required for nucleocapsid formation. J Virol. 1997;71(7):5040-5050.

Ooi BG, Miller LK. Regulation of host rna levels during baculovirus infection. Virology. 1988;166(2):515-523.

Palmer S, Wiegand AP, Maldarelli F, Bazmi H, Mican JM, Polis M, Dewar RL, Planta A, Liu S, Metcalf JA, Mellors JW, Coffin JM. New real-time reverse transcriptase-initiated pcr assay with single-copy sensitivity for human immunodeficiency virus type 1 rna in plasma. J Clin Microbiol. 2003;41(10):4531-4536.

Pang Y, Yu J, Wang L, Hu X, Bao W, Li G, Chen C, Han H, Hu S, Yang H. Sequence analysis of the Spodoptera litura multicapsid nucleopolyhedrovirus genome. Virology. 2001;287(2):391404.

Paradis E, Claude J, Strimmer K. Ape: Analyses of phylogenetics and evolution in $\mathrm{r}$ language. Bioinformatics. 2004;20(2):289-290.

Passarelli AL, Guarino LA. Baculovirus late and very late gene regulation. Curr Drug Targets. 2007;8(10):1103-1115.

Passarelli AL, Miller LK. Identification and characterization of lef-1, a baculovirus gene involved in late and very late gene expression. J Virol. 1993;67(6):3481-3488.

Payne. Insect pathogenic viruses as pest control agents. Fortschritte der Zoologie. 1986;32183200.

Pearson MN, Groten C, Rohrmann GF. Identification of the Lymantria dispar nucleopolyhedrovirus envelope fusion protein provides evidence for a phylogenetic division of the baculoviridae. J Virol. 2000;74(13):6126-6131.

Pearson MN, Rohrmann GF. Characterization of a baculovirus-encoded atp-dependent DNA ligase. J Virol. 1998;72(11):9142-9149.

Pearson MN, Russell RL, Rohrmann GF. Characterization of a baculovirus-encoded protein that is associated with infected-cell membranes and budded virions. Virology. 2001;291(1):22-31. 
Perera O, Green TB, Stevens SM, Jr., White S, Becnel JJ. Proteins associated with Culex nigripalpus nucleopolyhedrovirus occluded virions. J Virol. 2007;81(9):4585-4590.

Pilloff MG, Bilen MF, Belaich MN, Lozano ME, Ghiringhelli PD. Molecular cloning and sequence analysis of the Anticarsia gemmatalis multicapsid nuclear polyhedrosis virus gp64 glycoprotein. Virus Genes. 2003;26(1):57-69.

Pombo VV, Velloso LM, Ribeiro BM, Bao SN. Structural and ultrastructural changes during the infection of UFL-Ag-286 cells with the baculovirus AgMNPV. J Invertebr Pathol. 1998;72(3):239-245.

Prikhod'ko EA, Lu A, Wilson JA, Miller LK. In vivo and in vitro analysis of baculovirus ie-2 mutants. J Virol. 1999;73(3):2460-2468.

Quevillon E, Silventoinen V, Pillai S, Harte N, Mulder N, Apweiler R, Lopez R. Interproscan: Protein domains identifier. Nucleic Acids Research. 2005;33W116-W120.

Quinn GP, Keough MJ. Experimental design and data analysis for biologists. Cambridge: Cambridge University press; 2002.

Rahman MM, Gopinathan KP. Characterization of the gene encoding the envelope fusion glycoprotein gp64 from Bombyx mori nucleopolyhedrovirus. Virus Res. 2003;94(1):45-57.

Razuck FB, Ribeiro B, Vargas JH, Wolff JL, Ribeiro BM. Characterization of the p10 gene region of Anticarsia gemmatalis nucleopolyhedrovirus. Virus Genes. 2002;24(3):243-247.

Reed LJ, Muench H. A simple method of estimating fifty percent endpoints. The american journal of hygiene. 1938;27:493-497.

Ribeiro BM, Gatti CD, Costa MH, Moscardi F, Maruniak JE, Possee RD, Zanotto PMA. Construction of a recombinant Anticarsia gemmatalis nucleopolyhedrovirus (AgMNPV-2D) harbouring the beta-galactosidase gene. Arch Virol. 2001;146(7):1355-1367.

Rice WC, Miller LK. Baculovirus transcription in the presence of inhibitors and in nonpermissive drosophila cells. Virus Res. 1986;6(2):155-172. 
Riegel CI, Slavicek JM. Characterization of the replication cycle of the Lymantria dispar nuclear polyhedrosis virus. Virus Res. 1997;51(1):9-17.

Rodrigues JC, De Souza ML, O'Reilly D, Velloso LM, Pinedo FJ, Razuck FB, Ribeiro B, Ribeiro BM. Characterization of the ecdysteroid UDP-glucosyltransferase (egt) gene of Anticarsia gemmatalis nucleopolyhedrovirus. Virus Genes. 2001;22(1):103-112.

Rohrmann GF, Pearson MN, Bailey TJ, Becker RR, Beaudreau GS. N-terminal polyhedrin sequences and occluded baculovirus evolution. J Mol Evol. 1981;17(6):329-333.

Rohrmann GF. Evolution of occluded baculoviruses. In: Granados RR e Federici BA, editors. The biology of baculoviruses. Florida: Boca Raton; 1986. p. 203-215.

Rohrmann GF. Baculovirus Molecular Biology. 2008. Avaiable from http://www.ncbi.nlm.nih.gov/bookshelf/br.fcgi?book=bacvir. [17/10/2010].

Roncarati R, Knebel-Morsdorf D. Identification of the early actin-rearrangement-inducing factor gene, arif-1, from Autographa californica multicapsid nuclear polyhedrosis virus. J Virol. 1997;71(10):7933-7941.

Russell RL, Funk CJ, Rohrmann GF. Association of a baculovirus-encoded protein with the capsid basal region. Virology. 1997b;227(1):142-152.

Russell RL, Rohrmann GF. A 25-kda protein is associated with the envelopes of occluded baculovirus virions. Virology. 1993;195(2):532-540.

Russell RL, Rohrmann GF. Characterization of p91, a protein associated with virions of an Orgyia pseudotsugata baculovirus. Virology. 1997;233(1):210-223.

Saiki RK, Scharf S, Faloona F, Mullis KB, Horn GT, Erlich HA, Arnheim N. Enzymatic amplification of beta-globin genomic sequences and restriction site analysis for diagnosis of sickle cell anemia. Science. 1985;230(4732):1350-1354.

Sagisaka A, Fujita K, Nakamura Y, Ishibashi J, Noda H, Imanishi S, Mita K, Yamakawa M, Tanaka H. Genome-wide analysis of host gene expression in the silkworm cells infected with Bombyx mori nucleopolyhedrovirus. Virus Res. 2010;147(2):166-175. 
Schreiber V, Dantzer F, Ame JC, de Murcia G. Poly(adp-ribose): Novel functions for an old molecule. Nat Rev Mol Cell Biol. 2006;7(7):517-528.

Schultz KL, Friesen PD. Baculovirus DNA replication-specific expression factors trigger apoptosis and shutoff of host protein synthesis during infection. J Virol. 2009;83(21):1112311132.

Seshagiri S, Miller LK. Baculovirus inhibitors of apoptosis (iaps) block activation of sf-caspase1. Proc Natl Acad Sci USA. 1997;94(25):13606-13611.

Sheng Z, Charbonneau H. The baculovirus Autographa californica encodes a protein tyrosine phosphatase. J Biol Chem. 1993;268(7):4728-4733.

Shi C, Ingvardsen C, Thummler F, Melchinger AE, Wenzel G, Lubberstedt T. Identification by suppression subtractive hybridization of genes that are differentially expressed between nearisogenic maize lines in association with sugarcane mosaic virus resistance. Mol Genet Genomics. 2005;273(6):450-461.

Sieburth P, Maruniak JE. Growth characteristics of a continuous cell line from the velvetbean caterpillar, Anticarsia gemmatalis hübner (lepidoptera: Noctuidae) In Vitro Cel Dev Biol Plant. 1988;24:195-198.

Slack J, Arif BM. The baculoviruses occlusion-derived virus: Virion structure and function. Adv Virus Res. 2007;69:99-165.

Slack JM, Shapiro M. Anticarsia gemmatalis multicapsid nucleopolyhedrovirus v-trex gene encodes a functional 3' to 5' exonuclease. J Gen Virol. 2004;85:2863-2871.

Slack JM, Ribeiro BM, de Souza ML. The gp64 locus of Anticarsia gemmatalis multicapsid nucleopolyhedrovirus contains a 3 ' repair exonuclease homologue and lacks v-cath and chia genes. J Gen Virol. 2004;85:211-219.

Smith GE, Ju G, Ericson BL, Moschera J, Lahm HW, Chizzonite R, Summers MD. Modification and secretion of human interleukin 2 produced in insect cells by a baculovirus expression vector. Proc Natl Acad Sci USA. 1985;82(24):8404-8408. 
Smith GE, Summers MD, Fraser MJ. Production of human beta interferon in insect cells infected with a baculovirus expression vector. Mol Cell Biol. 1983;3(12):2156-2165.

Smith S. The world according to parp. Trends Biochem Sci. 2001;26(3):174-179.

Snel B, Bork P, Huynen MA. Genome phylogeny based on gene content. Nat Genet. 1999;21(1):108-110.

Soares JS, Ribeiro BM. Pathology of anticarsia gemmatalis larvae infected by two recombinant A. gemmatalis multicapsid nucleopolyhedroviruses. Res Microbiol. 2005;156(2):263-269.

Steinhaus EA, Richards AG. Insect pathology. An advanced treatise.: Academic Press; 1963.

Summers MD, Smith GE, Knell JD, Burand JP. Physical maps of Autographa californica and Rachiplusia ou nuclear polyhedrosis virus recombinants. J Virol. 1980;34(3):693-703.

Szewczyk B, Hoyos-Carvajal L, Paluszek M, Skrzecz I, Lobo de Souza M. Baculoviruses-- reemerging biopesticides. Biotechnol Adv. 2006;24(2):143-160.

Taguchi YH, Oono Y. Relational patterns of gene expression via non-metric multidimensional scaling analysis. Bioinformatics. 2005;21(6):730-740.

Tang XD, Xiao Q, Ma XC, Zhu ZR, Zhang CX. Morphology and genome of Euproctis pseudoconspersa nucleopolyhedrovirus. Virus Genes. 2009;38(3):495-506.

The Gene Ontology Consortium. Gene ontology: tool for the unification of biology. Nat. Genet. 2000;25(1):25-29.]

Theilmann DA, Stewart S. Molecular analysis of the trans-activating ie-2 gene of Orgyia pseudotsugata multicapsid nuclear polyhedrosis virus. Virology. 1992;187(1):84-96.

Thiem SM, Miller LK. Identification, sequence, and transcriptional mapping of the major capsid protein gene of the baculovirus Autographa californica nuclear polyhedrosis virus. J Virol. 1989;63(5):2008-2018. 
Tija ST, Carstens EB, Doerfler W. Infection of spodoptera frugiperda cells with autographa californica nuclear polyhedrosis virus ii. The viral DNA and the kinetics of its replication. Virology. 1979;99(2):399-409

Tomalski MD, Eldridge R, Miller LK. A baculovirus homolog of a cu/zn superoxide dismutase gene. Virology. 1991;184(1):149-161.

Tomalski MD, Wu JG, Miller LK. The location, sequence, transcription, and regulation of a baculovirus DNA polymerase gene. Virology. 1988;167(2):591-600.

van Munster M, Willis LG, Elias M, Erlandson MA, Brousseau R, Theilmann DA, Masson L. Analysis of the temporal expression of Trichoplusia $n i$ single nucleopolyhedrovirus genes following transfection of bt1-tn-5b1-4 cells. Virology. 2006;354(1):154-166.

van Oers MM, Abma-Henkens MH, Herniou EA, de Groot JC, Peters S, Vlak JM. Genome sequence of Chrysodeixis chalcites nucleopolyhedrovirus, a baculovirus with two DNA photolyase genes. J Gen Virol. 2005;86):2069-2080.

Vanarsdall AL, Pearson MN, Rohrmann GF. Characterization of baculovirus constructs lacking either the ac 101, ac 142, or the ac 144 open reading frame. Virology. 2007;367(1):187-195.

Vasconcelos SD, Williams T, Hails RS, Cory JS. Prey selection and baculovirus dissemination by carabid predators of lepidoptera. Ecol Entomol. 1996;21(1):98-104.

Vaughn JL, Goodwin RH, Tompkins GJ, McCawley P. The establishment of two cell lines from the insect Spodoptera frugiperda (lepidoptera; noctuidae). In Vitro. 1977;13(4):213-217.

Vilaplana L, O'Reilly DR. Functional interaction between Cydia pomonella granulovirus iap proteins. Virus Res. 2003;92(1):107-111.

Vlak JM, Klinkenberg FA, Zaal KJ, Usmany M, Klinge-Roode EC, Geervliet JB, Roosien J, van Lent JW. Functional studies on the p10 gene of Autographa californica nuclear polyhedrosis virus using a recombinant expressing a p10-beta-galactosidase fusion gene. J Gen Virol. 1988;69:765-776.

Volkman LE. Baculovirus infectivity and the actin cytoskeleton. Curr Drug Targets. 2007;8(10):1075-1083. 
Wang L, Yu J, Yin C, Li Z, Hu X, Pang Y. Characterization of a j domain gene of Spodoptera litura multicapsid nucleopolyhedrovirus. Virus Genes. 2002;25(3):291-297.

Wang R, Deng F, Hou D, Zhao Y, Guo L, Wang H, Hu Z. Proteomics of the Autographa californica nucleopolyhedrovirus budded virions. J Virol. 2010;

Wang XL, He RF, He GC. Construction of suppression subtractive hybridization libraries and identification of brown planthopper-induced genes. J Plant Physiol. 2005;162(11):1254-1262.

Wang Y, Choi JY, Roh JY, Woo SD, Jin BR, Je YH. Molecular and phylogenetic characterization of Spodoptera litura granulovirus. J Microbiol. 2008;46(6):704-708.

Washburn JO, Kirkpatrick BA, Volkman LE. Comparative pathogenesis of Autographa californica $\mathrm{M}$ nuclear polyhedrosis-virus in larvae of Trichoplusia ni and Heliothis virescens. Virology. 1995;209(2):561-568.

Washburn JO, Kirkpatrick BA, Volkman LE. Insect protection against viruses. Nature. 1996;383(6603):767-767.

Whitford M, Faulkner P. Nucleotide sequence and transcriptional analysis of a gene encoding gp41, a structural glycoprotein of the baculovirus Autographa californica nuclear polyhedrosis virus. J Virol. 1992;66(8):4763-4768.

Whitt MA, Manning JS. A phosphorylated 34-kda protein and a subpopulation of polyhedrin are thiol linked to the carbohydrate layer surrounding a baculovirus occlusion body. Virology. 1988;163(1):33-42.

Wickham TJ, Davis T, Granados RR, Shuler ML, Wood HA. Screening of insect cell-lines for the production of recombinant proteins and infectious virus in the baculovirus expression system. Biotechnol Progr. 1992;8(5):391-396.

Williams GV, Rohel DZ, Kuzio J, Faulkner P. A cytopathological investigation of autographa californica nuclear polyhedrosis virus p10 gene function using insertion/deletion mutants. J Gen Virol. 1989;70:187-202. 
Willis LG, Seipp R, Stewart TM, Erlandson MA, Theilmann DA. Sequence analysis of the complete genome of Trichoplusia ni single nucleopolyhedrovirus and the identification of a baculoviral photolyase gene. Virology. 2005;338(2):209-226.

Wilson ME, Mainprize TH, Friesen PD, Miller LK. Location, transcription, and sequence of a baculovirus gene encoding a small arginine-rich polypeptide. J Virol. 1987;61(3):661-666.

Wittwer CT, Herrmann MG, Moss AA, Rasmussen RP. Continuous fluorescence monitoring of rapid cycle DNA amplification. Biotechniques. 1997;22(1):130-131, 134-138.

Wolff JL, Valicente FH, Martins R, Oliveira JVC, Zanotto PMA. Analysis of the genome of Spodoptera frugiperda nucleopolyhedrovirus (SfMNPV-19) and of the high genomic heterogeneity in group II nucleopolyhedroviruses. J Gen Virol. 2008;89:1202-1211.

Wong ML, Medrano JF. Real-time pcr for mrna quantitation. Biotechniques. 2005;39(1):75-85.

Wormleaton S, Kuzio J, Winstanley D. The complete sequence of the Adoxophyes orana granulovirus genome. Virology. 2003;311(2):350-365.

Wu W, Liang H, Kan J, Liu C, Yuan M, Liang C, Yang K, Pang Y. Autographa californica multiple nucleopolyhedrovirus $38 \mathrm{k}$ is a novel nucleocapsid protein that interacts with vp1054, vp39, vp80, and itself. J Virol. 2008;82(24):12356-12364.

Wu WB, Lin TH, Pan LJ, Yu M, Li ZF, Pang Y, Yang K. Autographa californica multiple nucleopolyhedrovirus nucleocapsid assembly is interrupted upon deletion of the $38 \mathrm{k}$ gene. $\mathrm{J}$ Virol. 2006;80(23):11475-11485.

$\mathrm{Wu}$ X, Guarino LA. Autographa californica nucleopolyhedrovirus orf69 encodes an rna cap (nucleoside-2'-o)-methyltransferase. J Virol. 2003;77(6):3430-3440.

Wu X, Stewart S, Theilmann DA. Alternative transcriptional initiation as a novel mechanism for regulating expression of a baculovirus trans activator. J Virol. 1993;67(10):5833-5842.

Wu Y, Liu G, Carstens EB. Replication, integration, and packaging of plasmid DNA following cotransfection with baculovirus viral DNA. J Virol. 1999;73(7):5473-5480. 
Xiao H, Qi Y. Genome sequence of Leucania seperata nucleopolyhedrovirus. Virus Genes. 2007;35(3):845-856.

Xu YP, Ye ZP, Niu CY, Bao YY, Wang WB, Shen WD, Zhang CX. Comparative analysis of the genomes of Bombyx mandarina and Bombyx mori nucleopolyhedroviruses. J Microbiol. 2010;48(1):102-110.

Yamagishi J, Burnett ED, Harwood SH, Blissard GW. The acmnpv pp31 gene is not essential for productive AcMNPV replication or late gene transcription but appears to increase levels of most viral transcripts. Virology. 2007;365(1):34-47.

Yamagishi J, Isobe R, Takebuchi T, Bando H. DNA microarrays of baculovirus genomes: Differential expression of viral genes in two susceptible insect cell lines. Arch Virol. 2003;148(3):587-597.

Yeung KY, Ruzzo WL. Principal component analysis for clustering gene expression data. Bioinformatics. 2001;17(9):763-774.

Yu Q, Lin T, Feng G, Yang K, Pang Y. Functional analysis of the putative antiapoptotic genes, p49 and iap4, of Spodoptera litura nucleopolyhedrovirus with RNAi. J Gen Virol. 2008;89:18731880.

Zanotto PMA, Kessing BD, Maruniak JE. Phylogenetic interrelationships among baculoviruses evolutionary rates and host associations. J Invertebr Pathol. 1993;62(2):147-164.

Zanotto PMA, Krakauer DC. Complete genome viral phylogenies suggests the concerted evolution of regulatory cores and accessory satellites. Plos One. 2008;3(10).

Zdobnov EM, Apweiler R. Interproscan - an integration platform for the signature-recognition methods in interpro. Bioinformatics. 2001;17(9):847-848.

Zhang CX, Ma XC, Guo ZJ. Comparison of the complete genome sequence between C1 and G4 isolates of the Helicoverpa armigera single nucleocapsid nucleopolyhedrovirus. Virology. 2005;333(1):190-199. 
Zhu SY, Yi JP, Shen WD, Wang LQ, He HG, Wang Y, Li B, Wang WB. Genomic sequence, organization and characteristics of a new nucleopolyhedrovirus isolated from Clanis bilineata larva. BMC Genomics. 2009;10(91):1-9.

Zhu Y, Wang Z, Miller DJ, Clarke R, Xuan J, Hoffman EP, Wang Y. A ground truth based comparative study on clustering of gene expression data. Front Biosci. 2008;13:3839-3849. 